\title{
DİNÎ SEMBOLLERE YÖNELİK PSİKO-SOSYAL TUTUMLAR ÖLÇEĞİNİN GELIŞTİRİLMESİ VE BAZI DEĞİŞKENLERE GÖRE KARŞILAŞTIRILMASI
}

(D) Çiğdem GÜLMEZa

\author{
Fatma Zehra PATTABANOĞLUb
}

$\ddot{0 ̈ z}$

Dinî semboller ilk uygarlıklardan günümüze kadar insan yaşamının ayrılmaz unsurlarından birisi olmuştur. Ne var ki günümüz insanının bireysel ve toplumsal yaşamı üzerindeki etkisi bilimsel çalışmalarda henüz açık biçimde ortaya konulmuş değildir. Bu minvalde çalışmanın amacı dinî sembollere yönelik tutumları geçerli ve güvenilir olarak ölçebilen bir ölçme aracını geliştirmek ve bazı demografik değişkenlere göre karş̧laştırma yapmaktır. Geliştirilen taslak ölçek ilk olarak Kastamonu Üniversitesinin çeşitli fakültelerinde öğrenim gören 410 öğrenciye uygulanmıştır. Bu örneklemden elde edilen verilerle ölçeğin faktör yapısı açımlayıcı faktör analiziyle belirlenmiş, güvenirlik analizleri yapılmıştır. Toplam 38 maddenin yer aldığı üç alt faktörlü bir ölçek elde edilmiştir. Faktör yapısı belirlenen ölçek yaşları 18-65 arasında değişen 403 kişilik ikinci bir örnekleme uygulanmıştır. Bu örneklemden elde edilen verilere uygulanan doğrulayıcı faktör analizi neticesinde üç faktörlü yapı doğrulanmıștır. Elde edilen uyum indeksleri RMSEA $=0,081, \mathrm{NFI}=0,96, \mathrm{NNFI}=0,98, \mathrm{PNFI}=0,90$, $\mathrm{CFI}=0,98, \mathrm{IFI}=0,98, \mathrm{GFI}=0,87, \mathrm{AGFI}=0,89$ 'dur. Cronbach Alfa katsayısı; 1 . boyut için 0,97 , ikinci boyut için 0,89 ve üçüncü boyut için 0,84 'dir. Ayrıca her bir faktör için ortalama varyans değeri (AVE) ve kompozit güvenirlik (CR) değeri hesaplanmıştır. AVE değerleri faktörler için sırayla $0,62,0,54$ ve 0,58 , CR değeri ise sırayla $0,97,0,89$ ve 0,87 'dir. Bu sonuçlar ölçeğin ikinci örneklemde yaptığı ölçümün geçerlik ve güvenirliğinin yüksek olduğunu göstermiştir. İlaveten demografik değişkenlere göre dinî sembollere yönelik tutumlar karşılaştırılmıştır. Sonuçlara göre cinsiyet ve eğitim değişkenine göre dinî sembollere yönelik tutumlar farklılık göstermezken, dinî sembolleri tanıma düzeyi, öznel din algısı, yaş ve gelir değişkenleri açısından gruplar arasında anlamlı farklılıklar görülmüştür.

a Dr. Öğr. Üyesi., Kastamonu Üniversitesi, gulmezcigdem@gmail.com

b Doç. Dr., Kastamonu Üniversitesi, f.zehrapattabanoglu@hotmail.com 
Anahtar kelimeler: Din psikolojisi, Felsefe, Psiko-sosyal tutum, Dinî semboller, Ölçek, Geçerlik, Güvenirlik.

\section{淡淡 \\ THE DEVELOPMENT OF THE SCALE OF PYCHOSOCIAL ATTITUDES TOWARD RELIGIOUS SYMBOLS AND THE COMPARISON ACCORDING TO SEVERAL VARIABLES}

Religious symbols have been an integral part of human life since the first civilizations. However, its impact on the individual and social lifes of today's people has not been clearly revealed in scientific studies yet. In this respect, the aim of the study is to develop an attitude scale towards religious symbols, to make validity and reliability analysis and to make comparisons according to some personal variables. The draft scale developed was first applied to 410 students studying at various faculties of Kastamonu University. With the data obtained from this sample, the factor structure of the scale was determined by exploratory factor analysis, and reliability analysis were conducted. A scale with three sub-factors including 38 items in total was obtained. That scale was determined factor structure was applied to a second sample. The second sample's age range is between 18 and 65 years. The three-factor structure was confirmed as a result of the confirmatory factor analysis applied to the data obtained from this sample. The fit indices obtained are RMSEA $=0.081, \mathrm{NFI}=$ $0.96, \mathrm{NNFI}=0.98, \mathrm{PNFI}=0.90, \mathrm{CFI}=0.98, \mathrm{IFI}=0.98, \mathrm{GFI}=0.87, \mathrm{AGFI}=0.89$. Cronbach Alpha coefficient; 0.97 for the 1st dimension, 0.89 for the second dimension, and .84 for the third dimension. In addition, average variance extracted (AVE) value and composite reliability (CR) value were calculated for each factor. AVE values for factors are $0.62,0.54$ and 0.58 , respectively, while CR value is $0.97,0.89$ and 0.87 , respectively. These results showed that the validity and reliability of the measurement made by the scale in the second sample was high. In addition, attitudes towards religious symbols were compared according to demographic variables. According to the results, while attitudes towards religious symbols did not differ according to gender and education variables, significant differences were observed between the groups in terms of the level of recognition of religious symbols, subjective perception of religion, age and income variables.

[The Extended Abstract is at the end of the article.]

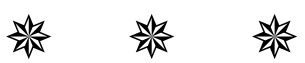

\section{Giriş}

Dinî semboller, Antikçağdan beri görünenle görünmeyen arasında köprü vazifesi yaparak, insanın kutsalla iletişime geçmesinde aracı rolü 
üstlenmişlerdir. Kavramlar, şekiller, mekânlar ve ritüeller şeklinde insan ve toplum hayatının vazgeçilmez unsurları arasına giren bu semboller bilinmeyenin anlaşılmasında kolaylık sağlamışlardır. Ancak sosyal bilimler sahasında pek çok kavramın karşı karşıya olduğu anlam çeşitliliği ve kargaşası sembol için de geçerlidir. Bu sebeple öncelikle sembolün kökenini ve dinî sembolün düşünce tarihindeki yerinin tespit edilmesinde fayda bulunmaktadır.

Kökeni Grekçe olan sembol İbranicede 'mashal', Grekçede 'symballein', Yunancada 'symbolon', İtalyancada 'simbolo', Almancada 'symbol, Fransızcada 'symbole' olarak geçmektedir. Türkçeye Fransızca 'symbole' kelimesinden geçmiş olan sembolün Büyük Türkçe Sözlük'te karşıllğı "duyularla ifade edilemeyen bir şeyi belirten somut nesne, işaret, remiz, rumuz, timsal, simge" (TDK, 2020a) dir. Aynı sözlüğe sembolü açıklayan kavramların nasıl tanımlandığına bakıldığında ise yine aynı kelimelerin birbirini açıklamak için kullanıldığı görülmektedir (TDK, 2020a). ${ }^{1}$ Oxford Etimoloji Sözlügü'ne göre Grekçe atmak anlamına gelen 'ballein' fiiliyle bilirlikte anlamına gelen 'syn' önekinin birleşiminden olan kelime 'sumbolon' formunda işaret, simge, şifre anlamlarına gelirken, geç Latinceye 'symbolum' olarak geçmiştir. 15. yüzyılda Hıristiyan inancının, öğretisinin özeti, 16. yüzyılda başka bir şeyi temsil eden bir şey, 17. yüzyılda yazılı karakter anlamlarını taşımıştır (Hoad, 2002, s. 478). Öte yandan Grek döneminden Ortaçağ Hıristiyan dünyasına kadar kelimenin sahip olduğu metafizik alanda temsiliyet niteliğini gösteren zengin örnekler bulunmaktadır. ${ }^{2}$ Modern dönemde ise, sembolün kutsalın taşıyıcısı olma veçhesi zayıflamış ve seküler alanın simge temsiliyeti ile aynı düzleme gelmiștir (Zeyrek, 2016, s. 202).

Bilindiği üzere tarihsel olarak köklü bir geçmişe sahip olan semboller felsefe, teoloji, edebiyat, dil bilimi, sanat, antropoloji, sosyoloji, psikoloji gibi sosyal bilimlerin hemen hemen bütün disiplinlerini ilgilendirmektedir. Neoplatonistlerden beri özellikle filozofların ve teologların ilgisine mazhar olan semboller konusu, 20. yüzyılda gösterge bilimciler tarafından ele alınmış ve problemin teorik boyutu üzerinde durulmuştur. Böylece gösterge bilimin kurucularından sayılan Charles Sanders Peirce, sembol tartışmalarına yeni bir boyut kazandırmıștır. Onun işaret, sembol, indeks ve simge terimleri arasında yaptığı ayrım, diğer bilim insanları için de teşvik edici olmuştur. Sembol üzerine çok daha iddialı tezler ileri süren (Struck,

1 Örneğin remizin açıklaması "simge", rumuzun açıklaması "simge", timsalin açıklaması yine "simge" olarak geçmektedir. Güncel Türkçe Sözlük, "remiz", "rumuz","timsal” (TDK, 2020, Erișim 12 Eylül 2020).

2 Ayrıntılı bilgi için bkz. (Struck, 2005, ss. 8906-8915). 
2005, s. 8912) filozof Ernest Cassirer ise, Aristoteles'ten beri öne sürülen "düşünen hayvan" tanımlamasına karşı çıkarak, insanı tanımlamak için gerekli anahtar kavramın sembol olduğunu söylemiştir. Cassirer'e göre insan sembolleştiren hayvandır (animal symbolicum). Çünkü insanı diğer canlılardan ayıran dil, din, mit ve sanat gibi kavramlar sembolleştirme kapasitesinin ürünüdür. Dahası insanın tüm zihinsel işlevlerini kuşatan tek kavram, sembolleştirmedir (Cassirer, 1980, ss. 33-34). Diğer taraftan "gösteren" ve "gösterilen" arasındaki ilişkiyi dinî semboller alanında kuran isim, Dinler Tarihçisi Mircea Eliade olmuştur. Eliade, Cassirer gibi sembolizmin dili ve yargıları önceleyen insan özünün bir parçası olduğunu vurgulamıştır (Eliade, 1992, s. XIX). Eliade'ye göre semboller insanın idrak ve kontrolünün ötesindeki gerçekliğin belirli boyutlarını ortaya çıkarmaktadır.

Modern antropoloji biliminin doğuşuyla sembol çalışmaları için "primitif" toplumlardan doğrudan veri toplanmıştır. Elde edilen bu verilere titiz biçimde uygulanan bilimsel yöntemlerle semboller, modern eleştirel bilincin kabul edebileceği soyutlamalar biçiminde izah edilmeye başlamıştır. Antropolojinin kurucu isimlerinden Edward Burnett Taylor ve James G. Frazer gibi isimler kültürlerde sembolik sistemlerin ortaya çıkışını izah etmeye çalışarak, akılcı ve açıklayıcı bir yaklaşım tarzı sunmuşlardır. Buna ilaveten Taylor, sembolik sürecin kaynağında animizm olduğunu ileri sürmüştür (Struck, 2005, s. 8910).

Sosyolojinin kurucu isimlerinden Emile Durkheim, sembollerin kökeninden ziyade toplumsal sonuçlarını ortaya çıkarmaya çalışmıştır. Durkheim, "Semboller toplumsal kökenler ve süreklilik için aslidir." (Durkheim, 2005, s. 21), "Bütün inanç sistemlerinin ve kültürlerin temelinde, zorunlu olarak belli sayıda temel semboller ve ayin uygulama tarzlarının olması gerekir." (Durkheim, 2005, s. 21) şeklindeki izahlarıyla sembollerin toplumsal açıdan vazgeçilmezliğini vurgulamıştır. Ona göre semboller ve ayinler nerede olursa olsun aynı işleve sahiptirler, toplumsal hayatın varlığı ve bütünlüğü onlara bağlıdır.

Derinlik psikolojisine gelince 20. yüzyılın başında Freud ve ardından Jung farklı bir sembol tasavvuru geliştirmiştir. Freud psikanalitik kuramını sembolik bir sistem üzerine kurmuștur. "Oedipus kompleksi" ${ }^{3}$ onun kuramının en bilinen sembolik izahlarından biridir. Buna göre semboller 
bilinçdışının en üst düzeydeki tezahürüdür. İnsan benliğinin keşfedilmesi ise ancak rüyalarda ortaya çıkan sembollerin dilinin çözülmesine bağlıdır. Freud rüyada ortaya çıkan sembolleri nevrotik durumları çözmenin anahtarı olarak görürken, Freud'un ifadesiyle Jung ise sembolleri, nevrozlarla dinsel mitolojik düşlemleri uzlaştırma vasıtası (Freud, 2005, s. 215) olarak görmüştür. Jung'a göre semboller kolektif bilinçdışına ait unsurlardır. Jung'un teorisinde semboller, insanın psişik ve manevi gelişimini uyaran ve besleyen arketiplere bağlıdır. Ona göre sembol insanın en yüce arzularından doğmakta, varlığının en derin köklerinden ortaya çıkmakla birlikte, psişenin en alt ve en ilkel düzeylerinden de aynı ölçüde kaynaklanmalıdır. Bu sebeple tez ve antitez gibi karşıt zihinsel işlevlerin ürünü olan sembol, sezilen ama anlamı asla tam olarak bilinmeyendir (Jung, 2016, ss. 69-71). Bu bağlamda sembol bilinmeyeni en iyi şekilde ifade ettiği, yani anlama gebe olduğu müddetçe yaşayacaktır. Ancak anlamın açık ve anlaşılır olduğu durumda yani anlam doğduğunda sembol artık ölecektir (Jung, 2016, s. 65). Jung'a göre Freud'un ileri sürdüğü bastırılmış isteklerin, arzuların veya acı veren yaşantıların rüyalarda ortaya çıkardığı semboller, sembol değil sadece birer semptomdur (Jung, 2016, s. 68).

Tillich ve Jung gibi sembollerin simge, imge, işaret, alegori, ikon gibi kelimelerle fark gözetilmeksizin kullanılmasını eleştiren Durand'a göre sembol "anlatılamaz ve görünmez bir gösterilene gönderen ve bundan dolayı da anımsayamadığı bu denkliği somut olarak tecessüm etmek zorunda olan ve bunu da yani uygunsuzluğu tükenmez bir biçimde düzelten ve tamamlayan ikonografik, ritüel, mitik yinelemeler oyunu aracılığıyla yapan işarettir."(Durand, 2017, s. 24). Tokat'ın aktardığı üzere Tillich, sembolün gerçek anlamının dışına taşırılarak geniş anlam kazanmasının dilbilimdeki gelişmelerden sonra olduğunu, kelimenin gerçek anlamını ifade etmek için bir sıfat kullanmanın zorunlu olduğunu belirmektedir. Bu nedenle Tillich, dil, din, tarih ve sanat alanlarındaki sembolleri; "temsili semboller", matematik ve mantık alanındaki sembolleri ise; "zihinsel semboller" olarak sinıflandırmıştır (Tokat, 2012, s. 12).

Fromm ise en genel anlamıyla sembolleri üç sınıfta incelemiştir: Birincisi; dil göstergeleri gibi, genelde nedensiz olarak ortaya çıan geleneksel sembollerdir. İkincisi; bazı varlıkların, rastlantısal olarak başlarından geçen bazı tecrübelerden dolayı, kendi dışındaki bir şeye işaret etmesiyle oluşan rastlantısal sembollerdir. Bunlar uykuda insanın bilinçaltının canlanması suretiyle gördüğü rüyaların ruh halini yansıtması gibi oluşmaktadır. Üçüncüsü; evrensel sembollerdir ki, bu semboller ile yansıttıkları gerçeklikler arasında analojik bir bağ bulunmaktadır. Analojik 
bağdan dolayı, bu evrensel semboller, her zaman herkes tarafından kavranabilme özelliğine sahiptirler (Fromm, 1992, ss. 24-31).

Anlaşlan odur ki, Cassirer, Eliade, Tillich, Durand gibi isimler bu tanımlayıcı nitelikleri vurgulayarak sembolü, sürekli olarak din ile özel bir ilişki içinde sunmaktadır. Nitekim bilgi, duygu ve davranışı içeren dinî tecrübede amaç, hakikate erme ve nihayetinde mutluluktur. Ancak sınırlı bir yaratılışa sahip insanın dili ve aklı, aşkın olan kutsalı anlama noktasında yeterli olmadığı için, Tanrı'yı ve dinî öğretileri daha iyi anlama konusunda sembolik olan din diline başvurmaktadır. Zira sembolün somut ve soyut olmak üzere iki yönü vardır ve bu yönlerden somut olanı, herhangi bir objeyi ve o objenin anlamını oluşturan tecrübelerden meydana gelmektedir. Soyut olan ise, bu tecrübelerde yansıyan soyut ya da aşkın gerçekliktir. İște bu objenin anlamlarını yansıtan tecrübelerle, soyut ya da aşkın gerçeklikleri analojiye dayalı olarak ileten dilsel ya da görüntüsel göstergelere götüren semboller, kişiye ve topluma yol gösterir (Yavuz, 2006, ss. 238-246, 392394). Semboller kişide önceden var olan bilgiyi hatırlatıp, belli bir yönde davranmaya sevk etmekte iken; dinî sembolizm bir şeyi akla getirmekten ziyade, insanî tecrübelerin ötesindeki şeylerin bilgisini getirmek üzere duyularımıza nesneler veya zihnimize fikirler sunar (Uluç, 2015, s. 58). Bu açıdan dinî sembolizmin iki tür çalışma alanından söz edilebilir: Bunlardan birisi, ibadetler ve ayinler esnasında oluşan yoğun duyguları ifade etmek için kullanılırken; diğeri, Tanrı'yı anlama ve dile getirme sorunudur (Uluç, 2015, s. 59). Esas itibarıyla dinî bakımdan Tanrı, imanın temel sembolü kabul edilir. Bununla birlikte imanın diğer bir semboller öbeği, kutsal olanın şeylerde, olaylarda, kişilerde ve topluluklarda, sözcükler ve belgelerdeki tezahürleri ortaya çıkar. Bütün bu kutsal nesneler alanı bir semboller hazinesi olarak temayüz etse de kutsal şeyler, kendi içlerinde kutsal olmayıp, bütün kutsiyetin ötesindeki kaynağa işaret ederler (Tillich, 2000, s. 770). Tanrı'ya ilişkin değişik kavramların kullanılmasında, çeşitli semboller dinî kültürün dayandığı bir temel haline gelir. İnsanın, varoluşsal sorgulamaları ve anlam arayışı bu çerçevede farklı bir renk kazanır (Aydeniz, 2011, s. 77).

Diğer taraftan Lawson ve McCauley dinî ritüelleri önemli sembolik bir organizasyon olarak gören bilişsel bir yaklaşım geliştirmiştir. Onlar ritüellerin kontrol, güç ve değişimle ilişkili olduğunu ileri sürmüşlerdir. Bu değişim kuşkusuz dinî dünyayla sınırlı kalmamakta, verdiği güç ve kontrol duygusuyla günlük yaşamdaki değişimleri de tetiklemektedir (Spilka, 2013, s. 163). Dinî ritüellerin kişiye ideal olanla özdeşleşmenin, belirsizlik yerine kesinliğin, acizlik yerine kudretin geçtiği hissini yaşatması gibi semboller de güven ve emniyet duygularını artırır, uyum ve başa çımada önemli olup, 
kaygı ve belirsizliği azaltır. Bu sebeple Mazumdar ve Mazumdar Güney Kaliforniya'daki Hindu göçmenlerin iyi oluş düzeylerini artırmak, kimliklerini korumak, dinî geleneklerini sürdürmek, geçmiş yaşamlarıyla ve insanlarla bağlarını korumak için modern rezidans veya evlerin bir bölümünü ibadethaneye çevirdiklerini, çeşitli ikonlarla, sembollerle donattıklarını belirtmektedir. Mazumdar ve Mazumdar bu durumu açıklamak için, "dinî bir yer olarak ev" veya "din ekolojisi" kavramlarını geliştirmiştir (Mazumdar \& Mazumdar, 2009).

Dinî sembollerin çan, ezan, salah, tekbir gibi "işitsel"; haç, balık, sekiz kolu şamdan, tekerlek, hilal, yıldız, kurban, cenaze törenleri, sema gösterisi, nazar tılsımı, seccade, tesbih, mushaf, cübbe, sarık, başörtüsü, sakal, mis, zemzem, türbe, mezar taşı, minber, mihrab gibi "görsel"; bunların ötesinde vecd, nur, ilham gibi "kavramsal" alanları vardır. Bunlar bir nesnenin veya eylemin geçerliliğini yok etmeyip bilakis bir nesneye veya bir eyleme yeni bir değer katarak, tarihsel geçerliliğini ihlal etmeden gerçeğe açılan kapıyı aralamaktadırlar. Ancak sembollerin kutsalla iletişime geçmede yardımcı olması, hayatı anlamlandırması, birey ve toplumu harekete geçirmesi, aidiyet duygusu oluşturması ve bunun üzerinden bireye kimlik kazandırması gibi pozitif; belli bir düşünceyi dikte etme, toplumsal ayrıştırma ve yıkıcı olma gibi negatif etkilerinin olabileceği göz önünde bulundurulmalıdır (Kızıl, 2018, ss. 34-39).

Dinî semboller çeşitli boyutlarıyla tartışılmaya devam etmekle birlikte, günümüz insanının onlara yönelik ne tür tutum sergilediği, yaşamında hangi oranda yer verdiği, kendini çevreleyen sembollerin psikolojik iyi oluşu üzerinde ne tür etkide bulunduğu gibi soruları cevaplayan çok az sayıda çalışma bulunmaktadır. Dahası bu türden çalışmalarda kullanılabilecek bir ölçme aracına ise ulaşılamamıştır. $\mathrm{Bu}$ sebeple araştırmada öncelikle dinî sembollere yönelik psiko-sosyal tutumları tespit edebilecek psikometrik yeterlilikte bir ölçme aracı geliştirmek lüzumu doğmuştur. Bu minvalde ölçek çalışmasından sonra bazı değişkenler açısından, psiko-sosyal tutumların insanlar arasında nasıl farklılık gösterdiği analiz edilecektir.

A. Dinî Sembollere Yönelik Psiko-sosyal Tutumlar Ölçeği: Birinci Çalışma

\section{Yöntem}

\section{a. Çalıșma Grubu}

Araştırmanın birinci örneklem grubunu Kastamonu Üniversitesi Fen Edebiyat Fakültesi, Mühendislik Fakültesi, İlahiyat Fakültesi ve Eğitim 
Fakültesinde öğrenim gören 410 öğrenci oluşturmaktadır. Bu gruptan veriler yüz yüze anket uygulamasıyla toplanmıştır. Veri analizi için uygun olmayan formlar dışarıda tutularak 388 kişiye ait veri analizlere dâhil edilmiştir. Analize dâhil edilen öğrencilerin \%67,4'ü kadın (259 kişi) \%32,6'sı (125 kişi) erkektir. Öğrencilerin yaşı 17 ile 46 arasında değişmektedir ve öğrencilerin yaş ortalaması 20,33'tür.

\section{b. İşlem}

Dinî sembollere yönelik psiko-sosyal tutumları belirlemeyi hedefleyen ölçeğin geliştirilme aşamasında literatür taranma, madde havuzunu oluşturma, kapsam geçerliği için uzman görüşü alma, taslak ölçeği uygulama, geçerlik ve güvenirlik analizleri yaparak ölçeği en uygun hale getirme basamakları takip edilmiştir.

Bir kavramı veya bir fenomeni bilimsel ilke ve yöntemlere uygun biçimde tartışmaya açabilmenin ön koşullarından biri probleme uygun bir ölçme aracı varsa uyarlamak, yoksa geliştirmektir. Kuşkusuz ister uyarlama ister ölçek geliştirme olsun, öncelikle ölçümü yapılacak kavramın tanımını yapmak, kavramının özellik ve sınırlarını iyi bir şekilde belirlemek gerekmektedir. Dinî sembol ve sembolün kavramsal çerçevesini çizebilmek için öncelikle sözlükler, ihtisas sözlükleri, ansiklopediler ve bu konulara muhtasar çalışmalar incelenmiş, konu uzmanlarının görüşleri alınmıştır. Ölçek dinî sembollere yönelik psiko-sosyal tutumları belirlemeyi hedeflediği için belirlenen tutumun düşünsel, duyuşsal ve davranışsal öğeleriyle birlikte sembollere yönelik olumlu ve olumsuz tepki önermeleri yazılmıştır. 55 önermenin yer aldığı madde havuzu oluşturulmuştur. Taslak ölçek maddeleri kapsam geçerliğini kontrol için uzman görüşüne sunulmuştur. Din psikolojisi, din sosyolojisi ve dinler tarihi bölümünden üç öğretim üyesinin görüşleri dikkate alınmıştır. Bu süreçte uzmanlardan gelen dönütlere bağlı olarak bazı maddeler çıkarılmış, bazı maddeler yeniden düzenlenerek 50 maddelik taslak ölçek oluşturulmuştur. Taslak ölçek maddeleri beşli Likert formunda düzenlemiştir. Maddeler "Hiç katılmıyorum=1", Katılmıyorum=2, Kısmen katılıyorum=3, Katılıyorum=4, Tamamen Katılıyorum=5" biçiminde derecelendirilmiştir. Hazırlanan bu taslak form Kastamonu Üniversitesinde Fen Edebiyat Fakültesi, Mühendislik Fakültesi, İlahiyat Fakültesi ve Eğitim Fakültesinde öğrenim gören 410 öğrenciye uygulanmıștır.

Üniversite öğrencilerinden oluşan bu örneklemden elde edilen veriler geçerlik ve güvenirlik testleri öncesinde analize uygunluk açısından incelenmiştir. Kayıp verilerin rastlantısal olarak dağılım gösterip göstermediği Missing Value Analiziyle incelenmiş $(p>0,05)$ ve kayıp veriler 
için seriler ortalaması ataması yapılmıştır. Normallik sayıltısı için çarpıklık ve basıklık katsayıları incelenmiştir. Veriler analiz için uygun hale getirildikten sonra, ölçeğin faktör yapısını birlemek için açımlayıcı faktör analizi uygulanmış ve güvenirlik analizleri yapılmıștır.

\section{Bulgular}

\section{a. Ölçeğin Yapı ve Madde Analizi}

Toplanan veriler analize uygun hale getirildikten sonra açımlayıcı faktör analizine (AFA) tabi tutulmuştur. Açımlayıcı faktör analizi yapılmadan önce örneklem büyüklüğünün faktörleştirmeye uygunluğunu ve değişkenlerin çoklu normallik dağılımı gösterip göstermediğini test etmek için Kaiser-Meyer-Olkin (KMO) testi ve Bartlett küresellik testi yapılmıştır $(\mathrm{KMO}=0,94$, Bartlett's Testi $=9646,666, p=0,0008)$. Daha sonra temel bileşenler analizi ve varimax döndürme tekniği yöntemine göre AFA yapılmıştır. Varimax döndürme tekniğine boyutlar arasındaki korelasyon değerleri incelenerek karar verilmiştir. Faktörler arasında 0,30'dan küçük korelasyon değerlerinin olduğu durumlarda dik döndürme tekniklerinin kullanılması önerilmektedir (Bursal, 2017, s. 164). Aşağıda Tablo 2'de sunulan değerlerden hareketle varimax döndürme tekniğinin uygun olduğu düşünülmüştür.

Tablo 1. Dinî Sembollere Yönelik Psiko-sosyal Tutumlar Ölçeği Alt Boyutlar Arası Korelasyonlar

\begin{tabular}{|l|c|c|c|}
\hline & 1. Faktör & 2. Faktör & 3. Faktör \\
\hline 1. Faktör & - & 0,33 & $-0,22$ \\
\hline 2. Faktör & - & - & $-0,27$ \\
\hline$p<0,001$ & & \\
\hline
\end{tabular}

Yapılan ilk faktör analizi sonrasında, ölçek formunda yer alan 50 maddeden bazılarının birden fazla faktörde kabul edilebilir düzeyde faktör yükü ürettiği, bazı maddelerin anlam ve içerik olarak uygun olmayan faktörde yer aldığı ve bazı maddelerin de faktör yüklerinin 0,32'nin altında kaldığı gözlenmiştir. Bu maddeler analiz dışı bırakılarak analiz tekrar edilmiştir. Analiz sonucunda ölçekte yer alan 38 madde anlam ve içerik olarak birbiriyle uyumlu ve özdeğeri 1'den büyük 3 alt faktör altında toplanmıștır. Açıklanan varyans toplamda $\% 52,66$ 'dır. Birinci faktör toplam varyasın \%31,47'sini, ikinci faktör \%11,50'sini, üçüncü faktör ise \%9,68'ini açıklamıştır. Her faktörün özdeğeri (eigenvalues) sırayla 11,89, 3,26 ve 2,22 'dir. Özdeğeri 1'in üzerinde olan iki faktör daha vardır. Ancak hem yamaç 
birikinti grafiği incelendiğinde üçüncü faktörden sonra eğimin plato yapması hem de özdeğeri 1'den yüksek olan bu boyutların toplam varyansın \%5'inden daha azını açıklaması nedeniyle üç faktörlü yapı tercih edilmiştir. Yamaç birikinti grafiği aşağıda Şekil 1'de verilmiştir. Analiz sonucunda ortaya çıkan boyutlar içerdikleri maddeler açısından incelenerek isimlendirilmiştir. Faktörlerden birincisinde dinî sembollere yönelik olumlu bilişsel, duyuşsal ve davranışlar öğeler toplanmıştır. Bu boyut "dinî sembollere yönelik pozitif duygu-düşünce-davranışlar" olarak adlandırılmıştır. $\mathrm{Bu}$ boyuttaki madde faktör yükleri 0,45 ile 0,84 arasında değişmektedir. İkinci boyutta yer alan maddelerin sembollere yönelik olumsuz tutumlar ön plana çıkmış bu maddeleri karşılayan kavramsal yapının "toplumsal ayrıștırma unsuru olarak dinî semboller" olarak isimlendirilmesine karar verilmiştir. Bu boyuttaki maddelerin faktör yükleri 0,53 ile 0,75 arasında değişmektedir. Üçüncü boyutta toplanan maddelerin ise dinî sembollere yönelik saygı ve hoşgörü kavramı altında birleştiği görülmüş ve üçüncü boyutta "toplumsal saygı ve hoşgörü unsuru olarak dinî semboller" şeklinde isimlendirilmiştir. Bu boyuttaki maddelerin faktör yükleri de 0,51 ile 0,78 arasında değişmektedir.

Şekil 1. Yamaç Birikinti Grafiği

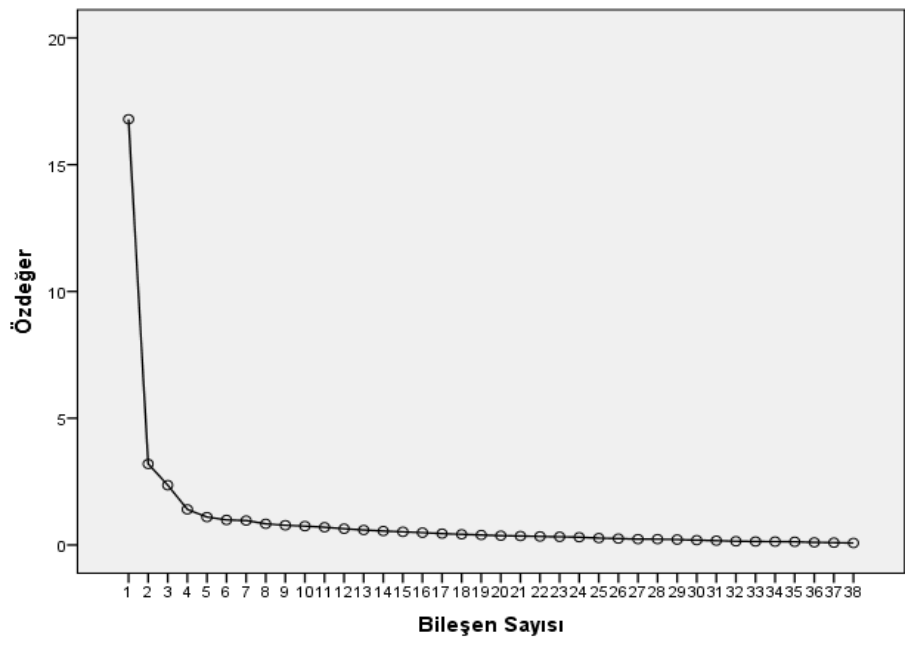


Tablo 2. Açımlayıcı Faktör Analizi Faktör Yükleri ve Madde Toplam Korelasyon ve \%27 Alt Dilim Üst Dilim Madde Ayırt Edicilik Değerleri

\begin{tabular}{|c|c|c|c|c|c|c|}
\hline \multicolumn{2}{|c|}{ Maddeler } & $\begin{array}{l}\text { Madde } \\
\text { Faktör } \\
\text { Yükleri }\end{array}$ & \multicolumn{2}{|c|}{$\begin{array}{l}\text { Madde Toplam } \\
\text { Korelasyonu }\end{array}$} & $\begin{array}{c}\text { Madde } \\
\text { Ayırt } \\
\text { Edicilik } \\
\text { t }\end{array}$ & $p$ \\
\hline \multicolumn{7}{|c|}{ 1. Boyut: Dinî Sembollere Yönelik Pozitif Duygu-Düşünce-Davranışlar } \\
\hline 1 & M1 & $\begin{array}{l}\text { Dinî semboller hayatımda önemli bir yer } \\
\text { tutar. }\end{array}$ & 0,733 & $0,760^{* *}$ & $-14,93$ & 0,001 \\
\hline 2 & M4 & Dinî semboller hayatıma anlam verir. & 0,755 & $0,767^{* *}$ & $-19,41$ & 0,001 \\
\hline 3 & M6 & $\begin{array}{l}\text { Dinî semboller davranışlarımı } \\
\text { yönlendirici etkiye sahiptir. }\end{array}$ & 0,705 & $0,711^{* *}$ & $-15,15$ & 0,001 \\
\hline 4 & M8 & $\begin{array}{l}\text { Dinî sembollerin Tanrıya yaklaşma hissi } \\
\text { yaşattığına inanırım. }\end{array}$ & 0,735 & $0,746^{* *}$ & $-20,73$ & 0,001 \\
\hline 5 & M9 & $\begin{array}{l}\text { Dinî sembollerin görünen dünya ile } \\
\text { görünmeyen aşkın alan arasında köprü } \\
\text { kurduğuna inanırım. }\end{array}$ & 0,765 & $0,777^{* *}$ & $-19,28$ & 0,001 \\
\hline 6 & M10 & $\begin{array}{l}\text { Dinî sembollere gösterilen değerin dinin } \\
\text { kendisine gösterilen değeri yansıttığını } \\
\text { düşünürüm. }\end{array}$ & 0,686 & $0,703^{* *}$ & $-15,31$ & 0,001 \\
\hline 7 & M13 & $\begin{array}{l}\text { Dinî semboller toplumlara bir ideal } \\
\text { sunar. }\end{array}$ & 0,684 & $0,721^{* *}$ & $-15,50$ & 0,001 \\
\hline 8 & M14 & $\begin{array}{l}\text { Dinî semboller toplumsal kimliğin } \\
\text { oluşmasında önemli bir unsurdur. }\end{array}$ & 0,636 & $0,691^{* *}$ & $-23,43$ & 0,001 \\
\hline 9 & M20 & $\begin{array}{l}\text { Dinî sembolleri kullanmak beni } \\
\text { rahatlatır. }\end{array}$ & 0,819 & $0,826^{* *}$ & $-24,85$ & 0,001 \\
\hline 10 & M21 & $\begin{array}{l}\text { Dinî sembolleri etrafımda görmek bana } \\
\text { güven verir. }\end{array}$ & 0,806 & $0,830^{* *}$ & $-25,91$ & 0,001 \\
\hline 11 & M22 & Dinî sembolleri taşımak bana güç verir. & 0,813 & $0,828^{* *}$ & $-23,94$ & 0,001 \\
\hline 12 & M23 & $\begin{array}{l}\text { Etrafımda dinî sembolleri görmek beni } \\
\text { mutlu eder. }\end{array}$ & 0,784 & $0,807^{* *}$ & $-22,28$ & 0,001 \\
\hline 13 & M24 & $\begin{array}{l}\text { Dinî semboller kaygılarımın azalmasını } \\
\text { sağlar. }\end{array}$ & 0,840 & $0,841^{* *}$ & $-24,51$ & 0,001 \\
\hline 14 & M25 & $\begin{array}{l}\text { Dinî sembolleri kullandığımda kendimi } \\
\text { daha dindar hissederim. }\end{array}$ & 0,730 & $0,727^{* *}$ & $-24,81$ & 0,001 \\
\hline 15 & M26 & $\begin{array}{l}\text { Dinî sembollerin daha çok bulunduğu } \\
\text { mekânlar ibadet etme isteğimi artırır. }\end{array}$ & 0,768 & $0,782^{* *}$ & $-27,73$ & 0,001 \\
\hline 16 & M27 & $\begin{array}{l}\text { Dinî semboller dinî duygularımın canlı } \\
\text { kalmasını sağlar. }\end{array}$ & 0,822 & $0,839^{* *}$ & $-24,39$ & 0,001 \\
\hline
\end{tabular}


Çiğdem GÜLMEZ \& Fatma Zehra PATTABANOĞLU

\begin{tabular}{|c|c|c|c|c|c|c|}
\hline 17 & M28 & $\begin{array}{l}\text { Dinî semboller bireysel kimliğimi } \\
\text { güçlendirir. }\end{array}$ & 0,828 & $0,819^{* *}$ & $-24,85$ & 0,001 \\
\hline 18 & M29 & $\begin{array}{l}\text { Dinî semboller zorluklara dayanma gücü } \\
\text { verir. }\end{array}$ & 0,788 & $0,798^{* *}$ & $-13,92$ & 0,001 \\
\hline 19 & M30 & $\begin{array}{l}\text { Dinî semboller yaşadığım topluma ait } \\
\text { aidiyet duygumu güçlendirir. }\end{array}$ & 0,760 & $0,773^{* *}$ & $-12,71$ & 0,001 \\
\hline 20 & M33 & $\begin{array}{l}\text { Herhangi bir ortamda bulunan dinî } \\
\text { semboller ilgimi çeker. }\end{array}$ & 0,544 & $0,602^{* *}$ & $-13,30$ & 0,001 \\
\hline 21 & M34 & Dinî sembolleri kıyafetlerimde taşırım. & 0,535 & 0,525 & $-12,99$ & 0,001 \\
\hline 22 & M37 & $\begin{array}{l}\text { İnandığım dine ait sembolleri merak } \\
\text { eder, anlamını araştırırım. }\end{array}$ & 0,457 & $0,535^{* *}$ & $-11,39$ & 0,001 \\
\hline 23 & M35 & $\begin{array}{l}\text { Evimde süs eşyası olarak dinî sembolleri } \\
\text { kullanırım. }\end{array}$ & 0,546 & $0,544^{* *}$ & $-12,71$ & 0,001 \\
\hline 24 & M40 & $\begin{array}{l}\text { Doğum, ad koyma, cenaze, evlilik, vs. } \\
\text { törenlerde dinî sembolleri kullanırım. }\end{array}$ & 0,598 & $0,654^{* *}$ & $-13,30$ & 0,001 \\
\hline
\end{tabular}

1. Boyut Özdeğer: 11.89; Açıklanan varyans: \%31.47; Cronbach Alfa: 0.96

\section{Boyut: Toplumsal Ayrışma Unsuru Olarak Dinî Semboller}

\begin{tabular}{|c|c|c|c|c|c|c|}
\hline 25 & M41 & $\begin{array}{l}\text { Gündelik hayatta dinî sembollerin } \\
\text { görünür olması insanlar arasında } \\
\text { ayrımcılığı körükler. }\end{array}$ & 0,570 & $0,575^{* *}$ & $-14,37$ & 0,001 \\
\hline 26 & M42 & $\begin{array}{l}\text { Kamusal hayatta dinî semboller } \\
\text { yasaklanmalıdır. }\end{array}$ & 0,606 & $0,646^{* *}$ & $-19,41$ & 0,001 \\
\hline 27 & M43 & Dinî sembollerin çoğu hurafedir. & 0,620 & $0,633^{* *}$ & $-15,84$ & 0,001 \\
\hline 28 & M44 & $\begin{array}{l}\text { Dinî sembollerin görünür olması } \\
\text { insanlar arasında ön yargıyı artırır. }\end{array}$ & 0,752 & $0,716^{* *}$ & $-18,96$ & 0,001 \\
\hline 29 & M45 & $\begin{array}{l}\text { 21. yüzyılda dinî sembollerin insanların } \\
\text { hayatlarını etkilemesine anlam } \\
\text { veremiyorum. }\end{array}$ & 0,619 & $0,647^{* *}$ & $-18,53$ & 0,001 \\
\hline 30 & M46 & Dinî semboller siyasi anlam taşır. & 0,532 & $0,560^{* *}$ & $-15,20$ & 0,001 \\
\hline 31 & M47 & $\begin{array}{l}\text { Dinî semboller siyasi yöneticiler } \\
\text { tarafından kullanıldığında toplum içinde } \\
\text { ayrışmaya neden olur. }\end{array}$ & 0,589 & $0,588^{* *}$ & $-10,53$ & 0,001 \\
\hline 32 & M49 & $\begin{array}{l}\text { İnsanlara açık yerlerde dinî sembollerin } \\
\text { tașınmasından rahatsız olurum. }\end{array}$ & 0,572 & 0,568 & $-13,45$ & 0,001 \\
\hline 33 & M50 & $\begin{array}{l}\text { Dinî semboller insanlar arasında kin ve } \\
\text { nefret duygularının ortaya çımasına } \\
\text { neden olur. }\end{array}$ & 0,695 & $0,696^{* *}$ & $-16,73$ & 0,001 \\
\hline
\end{tabular}


Dinî Sembollere Yönelik Psiko-Sosyal Tutumlar Ölçeğinin Geliştirilmesi ve Bazı Değişkenlere Göre Karşılaştırılması

\begin{tabular}{|c|c|c|c|c|c|c|}
\hline \multicolumn{5}{|c|}{ 3. Boyut: Toplumsal Saygı ve Hoşgörü Boyutu Olarak Dinî Semboller } & \multirow[b]{2}{*}{$-14,65$} & \multirow[b]{2}{*}{0,001} \\
\hline 34 & M15 & $\begin{array}{l}\text { Dinî sembollere saygı insanlı̆̆ı̆ } \\
\text { gereğidir. }\end{array}$ & 0,609 & $0,724^{* *}$ & & \\
\hline 35 & M16 & $\begin{array}{l}\text { Farklı dinlerin sembollerinin etrafimda } \\
\text { olmasından rahatsız olmam. }\end{array}$ & 0,617 & $0,634^{* *}$ & $-17,06$ & 0,001 \\
\hline 36 & M17 & $\begin{array}{l}\text { İnsanlar özgürce dinî sembolleri } \\
\text { kamusal yaşamda kullanabilmelidir. }\end{array}$ & 0,514 & $0,690^{* *}$ & $-21,37$ & 0,001 \\
\hline 37 & M38 & Dinî sembollere karşı saygı gösteririm. & 0,780 & $0,779^{* *}$ & $-19,11$ & 0,001 \\
\hline 38 & M39 & $\begin{array}{l}\text { Dinî sembollere karşı yapılan } \\
\text { saygısızlıkların karşısında dururum. }\end{array}$ & 0,727 & $0,757^{* *}$ & $-16,76$ & 0,001 \\
\hline
\end{tabular}

3. Boyut Özdeğer: 2.22; Açıklanan varyans: \%9.68; Cronbach Alfa: 0.75

\section{b. Bilinen Grup Geçerliği}

Faktör yapısı belirlenen ölçeğe, anlamlı fark beklenen iki örnekleme ilişkin ortalamaların kıyaslanmasıyla gerçekleştirilen bilinen grup geçerliği uygulanmıştır. Bu örneklemde hiç dindar değilim diyenlerle, çok dindarım diyen iki grup t testi ile karşılaştırılmıştır. Analiz sonucunda dinî sembollere yönelik olumlu duygu-düşünce-davranışlar alt boyutuna ilişkin ortalama puanların gruplar arasında farklılaştığı görülmüştür [t(61)=-9,046, $p<0,05]$. Hiç dindar değilim diyenlerin bu boyuttan aldıkları ortalama puanlar $(\bar{X}=54,99, \quad N=24)$ çok dindarım diyen grubun ortalama puanlarından ( $\bar{X}=96,54, N=39$ ) anlamlı şekilde düşüktür. Toplumsal ayrışma unsuru olarak dinî semboller alt boyutu ortalama puanları gruplara göre farklılaşmıştır $[\mathrm{t}(61)=5,604, p<0,05]$. Hiç dindar değilim diyenlerin ortalama puanları $(\bar{X}=27,68, N=24)$, çok dindarım diyen grubun ortalama puanlarından $(\bar{X}=19,94, N=39$ ) anlamlı şekilde yüksektir. Toplumsal saygı ve hoşgörü unsuru olarak dinî semboller alt boyutunda $[\mathrm{t}(61)=-3,762, p<0,05]$ ise hiç dindar değilim diyenlerin ortalama puanları $(\overline{\mathrm{X}}=16,64, \mathrm{~N}=24)$ çok dindarım diyenlerin ortalama puanlarından $(\bar{X}=21,77, N=39)$ anlamlı biçimde düşüktür. Grupların ortalama puanları arasındaki bu anlamlı farklılıklar bilinen gruplar geçerliğine kanıt oluşturmaktadır.

\section{c. Güvenirliğe İlişkin Bulgular}

Faktör yapısı AFA ile ortaya konan ölçeğin güvenirlik analizleri yapılmıștır. 1. faktörün Cronbach Alfa değeri 0,96, 2. faktörün Cronbach Alfa 
değeri 0,81, 3. faktörün Cronbach Alfa değeri 0,75 olarak hesaplanmıștır.

Ayrıca her bir alt boyutu oluşturan maddelerin ait oldukları faktörün toplam puanıyla olan korelasyon değerleri Tablo 1'de verilmiştir. 1. faktörü oluşturan maddelerin madde toplam korelasyon değerleri 0,52 ile 0,84 arasında; 2. faktörü oluşturan maddelerin madde toplam korelasyon değerleri 0,55 ile 0,79 arasında; 3. faktörü oluşturan maddelerin madde toplam korelasyon değerleri 0,63 ile 0,77 arasında değişmektedir.

Alt ölçeklerin madde ayırt ediciliğine alt $\% 27$ ve üst $\% 27$ 'lik grupların puanlarının karşılaştırılmasıyla bakılmıştır. Tablo 1'de görüldüğü gibi tüm t değerleri anlamlıdır $(p<0,001)$. Bu sonuçlar ölçekteki maddelerin ayırt ediciliklerinin yüksek olduğunu göstermektedir.

Ölçeğin her bir alt faktörünün iki yarı güvenirliğine de bakılmıştır. Eşdeğer formun bulunmadığı durumlarda test yarılama güvenirliği tercih edilen bir yöntemdir (Seçer, 2017, s. 214). İki yarı güvenirliğinde Sperman Brown korelasyon değerinin faktörler için sırayla 0,90, 0,87, 0,82 olduğu, Guttman Split-Half değerinin ise 0,93, 0,79, 0,71 olduğu görülmüştür.

Tablo 3. Güvenirlik Analizi Sonuçları

\begin{tabular}{|l|c|c|c|}
\hline Ölçek Boyutları & $\begin{array}{c}\text { Crohbach } \\
\text { Alfa }\end{array}$ & $\begin{array}{c}\text { Sperman Brown } \\
\text { İki Yarı } \\
\text { Korelasyonu }\end{array}$ & $\begin{array}{c}\text { Guttman } \\
\text { Split-Half }\end{array}$ \\
\hline 1. Boyut(Pozitif Duy-Düş-Dav) & 0,962 & 0,90 & 0,93 \\
\hline 2. Boyut (Top. Ayrışma Unsuru) & 0,810 & 0,87 & 0,79 \\
\hline 3. Boyut (Top. Saygı ve Hoşgörü U) & 0,751 & 0,82 & 0,71 \\
\hline
\end{tabular}

\section{B. Dinî Sembollere Yönelik Psiko-sosyal Tutumlar Ölçeği: İkinci Çalışma \\ İkinci çalışmanın amacı dinî sembollere yönelik psiko-sosyal tutumlar ölçeği için elde edilen üç faktörlü yapının yeni bir örneklemden elde edilen verilerde benzer sonuçlar verip vermediğini sınamak ve dinî sembollere yönelik psiko-sosyal tutumların bazı değişkenlerle ilişkisine bakmaktır.}

\section{Yöntem}

\section{a. Çalışma Grubu}

İkinci çalışmanın çalışma grubunu online anket yöntemi ile ulaşılan Türkiye'nin farklı şehirlerinde yaşayan 403 kişi oluşturmaktadır. Bu örneklemin yaşı 18 ile 65 arasında değişmektedir. Verilerin 379'u analize dâhil edilmiştir. Analize dâhil edilen kişilerin yaş ortalaması 31,22'dir. Katılımcıların \%65,17'i kadın (247 kişi), \%34,83’ü (132 kişi) erkektir. 
Örneklemin \%8,2'si (33 kişi) lise, \%70'i üniversite (282 kişi), \%21,8'i (88 kişi) lisansüstü düzeyde eğitime sahiptir. Aylık gelir durumları incelendiğinde örneklemin \%46,29'unun (175 kişi) 0-2400 TL arasında, \%22,48'inin (85 kişi) 2401-4999 TL arasında, \%19,31'inin (73 kişi) 50007999 TL arasında, \%11,90'ının ise (45 kişi) 8000 TL ve üstü aylık gelire sahip olduğu görülmüştür.

\section{b. Hipotezler}

H1. Dinî sembolleri tanıma düzeyine göre dinî sembollere yönelik psiko-sosyal tutumlar (dinî sembollere yönelik pozitif duygu-düşünce ve davranış boyutu, toplumsal ayrışma unsuru olarak dinî semboller boyutu, toplumsal saygı ve hoşgörü unsuru olarak dinî semboller boyutu) farklılaşmaktadır.

H2. Dinin önem düzeyine göre dinî sembollere yönelik psiko-sosyal tutumlar farklılaşmaktadır.

H3. Cinsiyete göre dinî sembollere yönelik psiko-sosyal tutumlar farklılaşmaktadır.

H4. Yaşa göre dinî sembollere yönelik psiko-sosyal tutumlar farklılaşmaktadır.

H5. Eğitim düzeyine göre dinî sembollere yönelik psiko-sosyal tutumlar farklılaşmaktadır.

H6. Gelir düzeyine göre dinî sembollere yönelik psiko-sosyal tutumlar farklılaşmaktadır.

\section{c. İşlem}

Birinci örneklemde geçerli ve güvenilir ölçüm yaptığı desteklenen ölçek ikinci bir örnekleme uygulanmıştır. Bu araştırmada kullanılan anket bataryasında ön uygulama neticesinde elde edilen ölçek ile katılımcıların yaygın olan bazı dinî sembolleri tanıyıp tanımadıklarını tespit etmek için kısa bir anket ve demografik bilgi anketi yer almıştır. Online anket yöntemiyle yaşları 18-65 arasında değişen 403 kişiden veri toplanılmıştır. Veriler analiz için uygun hale getirildikten sonra 379 kişinin verisi üzerinden doğrulayıcı faktör analizi (DFA) yapılmış, yakınsama geçerliği, ayırt edici geçerlik, Cronbach Alfa, kompozit güvenirlik (CR) değeri hesaplanmıştır. Daha sonra katılımcıların yaygın bazı dinî sembolleri tanıma düzeyleri, dinin önemi ve diğer bazı demografik değişkenlere (cinsiyet, yaş, eğitim, aylık gelir düzeyi) göre dinî sembollere yönelik psiko-sosyal tutumların farklılık gösterip göstermediği MANOVA analizi kullanılarak test edilmiştir. Kuramsal açıdan bağımlı değişkenler arası ilişkinin bulunduğu durumlarda bağımlı değişken 
adedince tek yönlü varyans analizi (ANOVA) yapmanın Tip I Hata miktarını artırabileceğini (Seçer, 2017, s. 107) göz önünde bulundurarak MANOVA tercih edilmiştir. Sonuçlar bulgular kısmında sırayla verilmiştir.

Toplanan veriler çok değişkenli istatistik sayıltılarını karşılaması bakımından incelenmiş, çok değişkenli istatistik işlemlerine uygun hale getirilmiştir. Malahobis uzaklıkları hesaplanarak uç değeler tespit edilmiş, uç değer gösteren veriler veri setinin dişında tutulmuştur. Normallik sayıltısının karşılanıp karşılanmadığını belirlemek için birden fazla yöntem bulunmaktadır. Bu araştırmada tekli normallik sayıltısı için çarpıklık ve basıklık katsayıları incelenmiştir.

\section{Bulgular}

\section{a. Doğrulayıcı Faktör Analizi}

Birinci çalışmada açımlayıcı faktör analiziyle elde edilen üç faktörlü yapının farklı bir örneklemde doğrulanıp doğrulanmadığı tespit etmek amacıyla doğrulayıcı faktör analizi (DFA) uygulanmıștır. Lisrel 8,2 programı aracılığıyla yapılan analiz sonrasında 38 maddenin tümünün 0,01 düzeyinde manidar olduğu (t değerinin 2,56'yı aşarsa 0,01 düzeyinde, 1,96'yı aşarsa 0,05 düzeyinde manidar olduğu belirtilmektedir (Çokluk vd., 2010, s. 304) görülmüştür. Maddelerin hata varyansları incelendiğinde hata varyanslarının 0,15 ile 0,76 arasında değiştiği 0,90'ın üzerine çıkan hata varyansının olmadığı görülmektedir. Mükemmel uyumun yakalandığı doymuş bir modelde Ki-Kare değerinin "0"a yakın olması, anlamlılık değerinin manidar olmaması ( $p>0,05)$, ve RMSEA değerinin 0'a yakın olması gerekir. Ancak Ki-Kare değerinin örnekleme göre manidar olma olasılı̆̆ yükseldiği için diğer uyum indeksleri de model kabulünde incelenmektedir. Kaynaklara göre RMSEA'nın $\leq 0,05$ 'in altında olması mükemmel, $\leq 0,08$ 'in altında olması iyi, $\leq 0,10$ 'ın altında olması zayıf; GFI, AGFI, CFI, NFI, NNFI, IFI, PGFI'nın $\geq 0,09$ ile $\geq 0,95$ arası olması iyi, $\geq 0,95$ ile 1 arasında olması ise mükemmel uyuma işaret etmektedir (Çokluk vd., 2010, ss. 267-272). Bazı kaynaklarda GFI ve AGFI $\geq 0,85$ olduğunda iyi uyuma işaret ettiği de belirtilmektedir (Seçer, 2017, s. 190).

Yapılan analizde bazı maddeler arasında Birinci düzey DFA sonucu uyum indeksleri şöyledir; $\left[x^{2}=1526,95, \mathrm{sd}=659, \quad p<0.001\right], \quad x^{2} / \mathrm{df}=2,31$, RMSEA $=0,081, \mathrm{NFI}=0,96$, NNFI $=0,98, \mathrm{PGFI}=0,90, \mathrm{CFI}=0,98, \mathrm{IFI}=0,98, \mathrm{GFI}$ $=0,87, \mathrm{AGFI}=0,89$ 'dur. Uyum iyiliğini değerlerini elde edebilmek için 1. ve 2 . maddenin arasında, 4. ve 5. madde arasında, 37. ve 38. madde arasında modifikasyon yapılmıştır. Elde edilen indekslerinin bazılarının iyi bazılarının mükemmel uyum kriterlerine uygun olmasından dolayı ölçeğin üç boyutlu 
yapısının bu örneklemde doğrulandığı söylenebilir. Aşağıda Tablo 4'te ikinci örneklemden elde edilen verilere uygulanan doğrulayıcı faktör analizi (DFA) standardize edilmiş yol katsayıları, $t$ değerleri, hata varyansları ve $r^{2}$ değerleri verilmiştir.

Tablo 4. Çalışma İçin Doğrulayıcı Faktör Analizi Faktör Yükleri ve Parametre Tahminleri

\begin{tabular}{|c|c|c|c|c|c|}
\hline No & Maddeler & SYK & t Değerleri & $\mathrm{HV}$ & $\mathrm{r}^{2}$ \\
\hline \multicolumn{6}{|c|}{ 1. Boyut } \\
\hline 1 & M1 & 0,73 & 12,03 & 0,46 & 0,54 \\
\hline 2 & M4 & 0,77 & 12,92 & 0,40 & 0,60 \\
\hline 3 & M6 & 0,68 & 10,79 & 0,54 & 0,46 \\
\hline 4 & M8 & 0,76 & 12,68 & 0,42 & 0,58 \\
\hline 5 & M9 & 0,73 & 11,87 & 0,47 & 0,53 \\
\hline 6 & M10 & 0,62 & 9,64 & 0,62 & 0,38 \\
\hline 7 & M13 & 0,75 & 12,44 & 0,44 & 0,56 \\
\hline 8 & M14 & 0,74 & 12,27 & 0,45 & 0,55 \\
\hline 9 & M20 & 0,89 & 16,08 & 0,21 & 0,79 \\
\hline 10 & M21 & 0,92 & 17,09 & 0,15 & 0,85 \\
\hline 11 & M22 & 0,91 & 16,88 & 0,16 & 0,84 \\
\hline 12 & M23 & 0,92 & 16,91 & 0,16 & 0,84 \\
\hline 13 & M24 & 0,91 & 16,67 & 0,17 & 0,83 \\
\hline 14 & M25 & 0,86 & 15,36 & 0,26 & 0,74 \\
\hline 15 & M26 & 0,85 & 14,95 & 0,28 & 0,72 \\
\hline 16 & M27 & 0,90 & 16,43 & 0,19 & 0,81 \\
\hline 17 & M28 & 0,89 & 16,09 & 0,21 & 0,79 \\
\hline 18 & M29 & 0,90 & 16,31 & 0,20 & 0,80 \\
\hline 19 & M30 & 0,87 & 15,64 & 0,24 & 0,76 \\
\hline 20 & M33 & 0,65 & 10,18 & 0,58 & 0,42 \\
\hline 21 & M34 & 0,64 & 10,15 & 0,58 & 0,42 \\
\hline 22 & M37 & 0,66 & 10,46 & 0,56 & 0,44 \\
\hline 23 & M35 & 0,61 & 9,52 & 0,62 & 0,38 \\
\hline 24 & M40 & 0,67 & 10,71 & 0,55 & 0,45 \\
\hline \multicolumn{6}{|c|}{ 2. Boyut } \\
\hline 25 & M41 & 0,63 & 9,58 & 0,60 & 0,40 \\
\hline 26 & M42 & 0,73 & 11,57 & 0,47 & 0,53 \\
\hline 27 & M43 & 0,74 & 11,84 & 0,45 & 0,55 \\
\hline 28 & M44 & 0,78 & 12,68 & 0,39 & 0,61 \\
\hline 29 & M45 & 0,75 & 11,90 & 0,44 & 0,56 \\
\hline 30 & M46 & 0,64 & 9,67 & 0,59 & 0,41 \\
\hline 31 & M47 & 0,49 & 7,11 & 0,76 & 0,24 \\
\hline
\end{tabular}


Çiğdem GÜLMEZ \& Fatma Zehra PATTABANOĞLU

\begin{tabular}{|l|l|l|l|l|l|}
\hline 32 & M49 & 0,72 & 11,24 & 0,49 & 0,51 \\
\hline 33 & M50 & 0,72 & 11,30 & 0,48 & 0,52 \\
\hline 3. Boyut \\
\hline 34 & M15 & 0,80 & 11,14 & 0,36 & 0,64 \\
\hline 35 & M16 & 0,86 & 10,19 & 0,69 & 0,31 \\
\hline 36 & M17 & 0,73 & 12,53 & 0,47 & 0,53 \\
\hline 37 & M38 & 0,72 & 7,97 & 0,46 & 0,54 \\
\hline 38 & M39 & 0,69 & 11,08 & 0,53 & 0,47 \\
\hline
\end{tabular}

\section{b. Yakınsama Geçerliği ve Ayırt Edici Geçerlik}

Dinî sembollere yönelik tutumlar ölçeğinin yakınsama geçerliği (convergent validity) ve ayırt edici geçerliği (discriminant validity) de incelenmiştir. Yakınsama geçerliği için Fornell ve Larcker formülüne göre boyut bazında ayrı ayrı AVE değeri hesaplanmıştır. Fornell ve Larcker'e göre (1981) yakınsak geçerlik faktör yüklerinin karesinin faktör madde sayısına bölünmesiyle bulunmaktadır. Fornell ve Larcker'e göre AVE değerin 0,5'in üzerinde olması ilgili faktörün yakınsama geçerliğinin yüksek olduğuna işaret etmektedir. Ölçeğin alt boyutlarının AVE değerleri sırayla 0,627, 0,541, 0,581'dir. Bu değerlerin tamamının 0,05'ten büyük olması yakınsama geçerliğine kanıt sunmaktadır. Fornell ve Larcker testi ayrıca ayrıt edici geçerliği incelemek için de kullanılmaktadır. Formüle göre AVE değerlerinin karekökünün her bir faktör için yapılar arasındaki korelasyonlardan yüksek olması ayırt edici geçerliğe işaret etmektedir. Ayırt edici geçerlik için AVE değerlerinin karekökünün faktörler arasındaki korelasyonlardan büyük olup olmadığı incelenmiştir. Sonuçlar ölçeğin ayırt edici geçerliğinin olduğunu göstermektedir.

Tablo 5. Ayırt Edici Geçerlik

\begin{tabular}{|l|c|c|c|}
\hline Faktörler & 1. Faktör & 2. Faktör & 3. Faktör \\
\hline 1. Faktör & $\mathbf{0 , 7 9 1}$ & & \\
\hline 2. Faktör & $-0,47$ & $\mathbf{0 , 7 3 5}$ & \\
\hline 3. Faktör & 0,68 & $-0,39$ & $\mathbf{0 , 7 6 2}$ \\
\hline
\end{tabular}

\section{c. Güvenirlik Analizi}

$\mathrm{Bu}$ çalışmada da faktör bazında güvenilirlik analizi için Cronbach Alfa ve birleşik güvenilirlik (composite reliability, CR) değerleri hesaplanmıştır. $\mathrm{Bu}$ örneklemde yapılan ölçüm için faktör bazında hesaplanan Cronbach Alfa katsayısı 1. faktör için $0,97,2$. faktör için $0,89,3$. faktör için ise 0,84 'tür. 
Kompozit güvenirlik (CR) birbirine yakın fakat hetorojen maddelerin güvenirliğini saptamak için kullanılmaktadır (Fornell \& Larcker, 1981). Chronbah Alfa değeri madde sayısının fazla olmasından etkilendiği için kompozit güvenirlik alternatif bir yöntem olarak önerilmektedir. CR'nin ise 0,70'in üzerinde olması gerekmektedir. Yapılan hesaplamalar neticesinde CR değerinin 0,70'in üzerinde oluğu görülmüştür.

Tablo 6. Güvenirlik Değerleri

\begin{tabular}{|l|l|l|}
\hline & Crohbach Alfa & CR \\
\hline 1. Boyut (Pozitif Duy-Düş-Dav) & 0,976 & 0,975 \\
\hline 2. Boyut (Ayrıștırıcı unsur) & 0,891 & 0,891 \\
\hline 3. Boyut (Saygı ve Hoşgörü) & 0,848 & 0,873 \\
\hline
\end{tabular}

\section{d. Bazı Değișkenlere Göre Dinî Sembollere Yönelik Psiko-sosyal}

\section{Tutumlar}

Araştırmanın ikinci örneklemine dinî sembollere yönelik pisiko-sosyal tutumlar ölçeğinin yanı sıra yaygın olan bazı dinî sembolleri tanıma düzeylerini tespit edecek 9 anket sorusu, tek maddeli dinin yaşamlarındaki önemi sorusu ve yaș, cinsiyet, eğitim, gelir düzeyini belirlemeyi hedefleyen demografik bilgi soruları sunulmuştur.

Tablo 7. Bazı Dinî Semboller ve Katılımcılar Tarafından Bilinme Yüzdeleri

\begin{tabular}{|c|c|c|c|c|}
\hline & & Evet & Hayır & $\begin{array}{l}\text { Fikrim } \\
\text { Yok }\end{array}$ \\
\hline 1 & $\begin{array}{l}\text { "Hilal" İslam kültürünün önemli sembollerinden } \\
\text { biridir. }\end{array}$ & $\begin{array}{l}308 \\
(\% 81,3)\end{array}$ & $\begin{array}{l}25 \\
(\% 6,6)\end{array}$ & $\begin{array}{l}46 \\
(\% 12,1)\end{array}$ \\
\hline 2 & $\begin{array}{l}\text { "Haç" çarmıha gerildikten sonra Mesih'in dirilişini } \\
\text { sembolize eden, aynı zamanda kurtuluş ve zafer } \\
\text { anlamına gelen Hıristiyanlığın sembolüdür. }\end{array}$ & $\begin{array}{l}296 \\
(\% 78,1)\end{array}$ & $\begin{array}{l}33 \\
(\% 8,7)\end{array}$ & $\begin{array}{l}50 \\
(\% 13,2)\end{array}$ \\
\hline 3 & "Balık" Hıristiyanlığın önemli bir sembollerindendir. & $\begin{array}{l}88 \\
(\% 23,2)\end{array}$ & $\begin{array}{l}189 \\
(\% 49,6)\end{array}$ & $\begin{array}{l}103 \\
(\% 27,2)\end{array}$ \\
\hline 4 & $\begin{array}{l}\text { Yanda verilen şekil "Davud yıldızı"dır ve } \\
\begin{array}{l}\text { Yahudilerin } \\
\text { sembollerindendir. }\end{array}\end{array}$ & $\begin{array}{l}298 \\
(\% 78,6)\end{array}$ & $\begin{array}{l}30 \\
(\% 7,9)\end{array}$ & $\begin{array}{l}51 \\
(\% 13,5)\end{array}$ \\
\hline 5 & "Kâbe" İslam dininin önemli sembollerindendir. & $\begin{array}{l}362 \\
(\% 95,5)\end{array}$ & $9(\% 2,4)$ & $8(\% 2,1)$ \\
\hline 6 & $\begin{array}{l}\text { Yanda verilen şekil çoğunlukla } \\
\text { "Gamalı haç" olarak bilinir. Fakat } \\
\text { Hinduizm'de yüreklilik ve refahı } \\
\text { simgeleyen “Swastika" sembolüdür. }\end{array}$ & $\begin{array}{l}171 \\
(\% 45,1)\end{array}$ & $\begin{array}{l}73 \\
(\% 19,3)\end{array}$ & $\begin{array}{l}135 \\
(\% 35,6)\end{array}$ \\
\hline
\end{tabular}




\begin{tabular}{|l|l|l|l|l|}
\hline 7 & $\begin{array}{l}\text { Yanda verilen şekil; “Aum (Om" olarak } \\
\text { bilinir. Hinduizm'de dinî ya da mistik } \\
\text { etkisi olduğuna inanılan sözcüklerin }\end{array}$ & $\begin{array}{l}173 \\
(\% 45,6)\end{array}$ & $\begin{array}{l}86 \\
(\% 27,7)\end{array}$ & $\begin{array}{l}120 \\
(\% 31,7)\end{array}$ \\
\hline 8 & $\begin{array}{l}\text { Yahudi erkekleri tarafından takılan başa takılan bir } \\
\text { tür küçük takke olan "Kipa" Yahudiliğin } \\
\text { sembollerindendir. }\end{array}$ & $\begin{array}{l}249 \\
(\% 65,7)\end{array}$ & $\begin{array}{l}45 \\
(\% 11,9)\end{array}$ & $\begin{array}{l}85 \\
(\% 24,4)\end{array}$ \\
\hline 9 & $\begin{array}{l}\text { At nalı, nazar boncuğu, Meryem Ana eli, fil gibi } \\
\text { semboller dinî sembollere dönüşmüş kültürel } \\
\text { sembollerdir. }\end{array}$ & $\begin{array}{l}241 \\
(\% 63,6)\end{array}$ & $\begin{array}{l}62 \\
(\% 16,4)\end{array}$ & $\begin{array}{l}76 \\
(\% 20,1)\end{array}$ \\
\hline
\end{tabular}

Katılımclların anket sorularına verdikleri cevaplar incelendiğinde en fazla doğru cevabın İslam'ın sembolleri olan hilal ve Kâbe sorularına (Hilal= \%81,3; Kâbe= \%95,5) verildiği görülmektedir. En az doğru cevap ise Hıristiyanlar için önemli olan balık sembolünün sorulduğu soruya $(\% 23,2)$ verilmiştir. Katılımcıların sembolleri tanıma düzeylerine göre dinî sembollere yönelik tutumların farklılık gösterip göstermediğini belirleyebilmek için katılımcılar anket sorularına verdikleri doğru cevaplara göre gruplandırılmıştır. Buna göre 0,1,2 ve 3 doğru cevabı olanlar 1. grup, 4, 5 ve 6 doğru cevabı olanlar 2. grup, 7, 8 ve 9 doğru cevabı olanlar ise 3 . gruptur. Dinî sembolleri tanımaya göre dinî sembollere yönelik tutumların farklılaşıp farklılaşmadığını belirlemek için tek yönlü MANOVA analizi yapılmıștır. MANOVA analizi yapılmadan önce MANOVA sayıltıları test edilmiştir. Tekli normallik için skewness (çarpıklık) ve kurtosis (basıklık) değerlerine bakılmıştır. Hiçbir skewness ve kurtosis değerlerinin $-1,5$ ve +1,5'i geçmediği görülmüştür. Tabachnick ve Fidell'e (2010, ss. 630-631) göre skewness ve kurtosis değerleri $+1,5$ ve $-1,5^{\prime}$ in altında olduğu durumlarda normallik sayıltısı karşılanmıştır.

Çalışmada elde edilen verilere MANOVA analizi uygulanacağı için tek değişkenler için normallik sınamasının yanında çok değişkenli normallik testi de uygulanmıştır. "Çok değişkenli normal dağılım örneklemde yer alan gözlemlerin, değişkenlerin tüm kombinasyonları açısından normal dağılım göstermesidir (Çokluk vd., 2010, s. 16). Çok değişkenli normallik sayıltısının karşılanıp karşılanmadığını belirlemek için Mahalanobis Uzaklık Katsayısı incelenmiştir. Pearson ve Hartley Mahalanobis uzaklık değerleri incelenirken değişken sayısına göre şu değerlerin dikkate alınmasını önermiştir (Seçer, 2017, s. 36):

Mahalanobis Uzaklık Değerleri; 2 yordayan değişken için: 13,82, 3 yordayan değişken için: 16,27, 4 yordayan değişken için: 18,47, 5 yordayan 
değişken için: 20,52, 6 değişken yordayan için: 22,46, 7 yordayan değişken için: 24,32 dir. Mahalanobis Uzaklık Katsayıları hesaplandıktan sonra uç değerler belirlenmiştir. Bu çalışma için üç yordayan değişken atandığı için 16,27 kritik değeri baz alınmıştır. Uç değerlerinin hiçbirinin Mahalonobis uzaklık değerinin 16,27'nin üzerinde olmadığı dolayısıyla bu uç değerlerin analizi olumsuz etkilemediği, çoklu normallik sayıltısının karşılandığı kabul edilmiştir. Aynı veri üzerinde ikiden fazla grup olduğu durumlarda Bonferroni düzeltmesi yapılmıştır. Gruplar arası farklılığın büyüklügünü belirlemek için ise eta kare ( $\eta 2$ ) etki değerine bakılmıştır. Cohen'e göre etki büyüklüğü değeri 0,06'ya kadar küçük, 0,14'e kadar orta, 0,14 ve üzeri ise büyük kabul edilmektedir (Akt. Akbulut, 2010, s. 137).

Tablo 8. Dinî Sembolleri Tanıma Düzeyine Göre Dinî Sembollere Yönelik Tutumların Karşılaştırması MANOVA Sonuçları

\begin{tabular}{|c|c|c|c|c|c|c|c|}
\hline Değişken & $\begin{array}{l}\text { Dinî } \\
\text { Sembolleri } \\
\text { tanıma }\end{array}$ & $\mathbf{N}$ & $\overline{\mathbf{X}}$ & ss & $\mathbf{F}$ & $p$ & Fark \\
\hline \multirow{4}{*}{$\begin{array}{l}\text { Olumlu } \\
\text { Duy-Düş- } \\
\text { Dav }\end{array}$} & 1.Grup & 66 & 80,15 & 19,48 & \multirow{4}{*}{2,98} & \multirow{4}{*}{0,052} & \multirow{4}{*}{-} \\
\hline & 2. Grup & 157 & 82,24 & 19,97 & & & \\
\hline & 3. Grup & 156 & 86,75 & 22,41 & & & \\
\hline & Toplam & 379 & 83,73 & 21,04 & & & \\
\hline \multirow{4}{*}{$\begin{array}{l}\text { Ayrıştırıcı } \\
\text { Unsur }\end{array}$} & 1.Grup & 66 & 22,56 & 6,75 & \multirow{4}{*}{0,46} & \multirow{4}{*}{0,629} & \multirow{4}{*}{-} \\
\hline & 2. Grup & 157 & 23,60 & 7,40 & & & \\
\hline & 3. Grup & 156 & 23,09 & 8,23 & & & \\
\hline & Toplam & 379 & 23,21 & 7,64 & & & \\
\hline \multirow{4}{*}{$\begin{array}{l}\text { Saygı ve } \\
\text { Hoşgörü }\end{array}$} & 1.Grup & 66 & 19,33 & 3,16 & \multirow{4}{*}{6,33} & \multirow{4}{*}{0,002} & \multirow{4}{*}{$1-3$} \\
\hline & 2. Grup & 157 & 20,42 & 3,27 & & & \\
\hline & 3. Grup & 156 & 21,06 & 3,44 & & & \\
\hline & Toplam & 379 & 20,49 & 3,37 & & & \\
\hline
\end{tabular}

Katılımcıların dinî sembolleri tanıma düzeyine göre dinî sembollere yönelik psiko-sosyal tutumları karşılaştırmak için tek faktörlü MANOVA analizi yapılmıştır. MANOVA sonuçları yorumlanmadan önce MANOVA analizi sayıltılarının karşılanıp karşılanmadığı kontrol edilmiştir. Öncelikle Box's M testi kullanılarak gruplar arası kovaryansın homojenliği test edilmiștir. Box's M testi sonucunda elde edilen $p$ değerinin 0,05 'ten büyük olması durumunda varyans-kovaryans eşitliğinden söz edilebilir. Box's M istatistiğine göre yayılma matrisinin homojenlik sayıltısını karşıladığı görülmüştür $\left(\mathrm{F}_{(12-205322,944)}=0,789, p>0,05\right)$. Daha sonra Levene testi kullanılarak her bir varyansın homojenliği test edilmiștir. Levene testi 
sonucu elde edilen $p$ değerinin 0,05 'ten büyük olması gerekmektedir. Buna göre üç grupta da varyansların homojen olduğu görülmüştür $(p>0,05)$. Multivariate test sonuçlarına göre dinî sembolleri tanıma değişkeni açısından bağımlı değiş̧enlerden en az biri anlamlı farklılık göstermiştir (Wilks' $\lambda=0,949, \mathrm{~F}_{(16-1192,107)}=0,949, p<0,05$ ). Bağıml değişkenlerdeki çok yönlü (multivariate) varyansın \%2,6'sı bağımsız değişken tarafından açıklanmaktadır $(\eta 2=0,026)$. Tablo 8'de tek faktörlü ANOVA sonuçları verilmiştir. Dinî sembolleri tanıma düzeylerine göre dinî sembollere yönelik pozitif duygu-düşünce-davranış boyutu puanları $\left(\mathrm{F}_{(2-376)}=2,981, p>0,05\right)$, toplumsal ayrışma unsuru olarak dinî semboller boyutu puanları $\left(\mathrm{F}_{(2-376)}=\right.$ $0,464, p>0,05$ ) farklılık göstermezken toplumsal saygı ve hoşgörü unsuru olarak dinî semboller boyutu ortalama puanları $\left(\mathrm{F}_{(2-376)}=6,337, p<0,05\right)$ farklılık göstermiştir. Bu boyutta hangi gruplar arasında ortalama puanların farklılaştığını görmek için Post Hoc analizlerinden Scheffe testi yapılmıştır. Analiz sonucunda dinî sembol anketinde 0-3 arasında doğru cevap verenlerden oluşan 1. grubun dinî sembollere yönelik saygı ve hoşgörü ortalama puanının en düşük, dinî semboller anketinde 7-9 arasında doğru cevap verenlerden oluşan 3. grubun ise dinî sembollere yönelik saygı ve hoşgörü ortalama puanın en yüksek olduğu görülmüştür. Sembolleri tanıma düzeyi artarken dinî sembollere yönelik saygı ve hoşgörü de artış göstermektedir.

Tablo 9. Dinin Önemi Algısına Göre Dinî Sembollere Yönelik Tutumların Karşılaştırması MANOVA Sonuçları

\begin{tabular}{|c|c|c|c|c|c|c|c|}
\hline Değişken & Dinin önemi & $\mathbf{N}$ & $\overline{\mathbf{X}}$ & ss & $\mathbf{F}$ & $p$ & Fark \\
\hline \multirow{5}{*}{$\begin{array}{l}\text { Olumlu } \\
\text { Duy-Düş- } \\
\text { Dav }\end{array}$} & 1.Hiç & 11 & 39,72 & 10,09 & \multirow{5}{*}{43,69} & \multirow{5}{*}{0,001} & \\
\hline & 2. Çok az & 16 & 59,37 & 16,99 & & & $1-3,4$ \\
\hline & 3. Önemli & 117 & 78,52 & 16,79 & & & $2-3,4$ \\
\hline & 4. Çok önemli & 235 & 90,05 & 19,16 & & & $3-4$ \\
\hline & Toplam & 379 & 83,73 & 21,04 & & & \\
\hline \multirow{5}{*}{$\begin{array}{l}\text { Ayrıştırıcı } \\
\text { Unsur }\end{array}$} & 1.Hiç & 11 & 35,63 & 7,33 & \multirow{5}{*}{25,54} & \multirow{5}{*}{0,001} & \\
\hline & 2. Çok az & 16 & 32,25 & 6,87 & & & $1-3,4$ \\
\hline & 3. Önemli & 117 & 24,13 & 7,02 & & & $2-3,4$ \\
\hline & 4. Çok önemli & 235 & 21,55 & 6,96 & & & $3-4$ \\
\hline & Toplam & 379 & 23,21 & 7,64 & & & \\
\hline \multirow{5}{*}{$\begin{array}{l}\text { Saygi ve } \\
\text { Hoşgörü }\end{array}$} & 1.Hiç & 11 & 17,72 & 4,94 & \multirow{5}{*}{4,07} & \multirow{5}{*}{0,007} & \multirow{5}{*}{$1-4$} \\
\hline & 2. Çok az & 16 & 19,50 & 4,03 & & & \\
\hline & 3. Önemli & 117 & 20,22 & 3,09 & & & \\
\hline & 4. Çok önemli & 235 & 20,83 & 3,31 & & & \\
\hline & Toplam & 379 & 20,49 & 3,37 & & & \\
\hline
\end{tabular}


"Din sizin için ne kadar önemlidir?" sorusuna verilen tepkilere göre dinî sembollere yönelik tutumların değişkenlik gösterip göstermediğini belirlemek için öncelikle Box's M testi kullanılarak gruplar arası kovaryansın homojenliği test edilmiştir. Box $\mathrm{M}$ istatistiğine göre yayılma matrisinin homojenlik sayıltısının karşılanmadığı görülmüştür $\left(\mathrm{F}_{(18-}{ }_{5010)}=1,742\right.$ $p<0,05)$. Daha sonra Levene Testi kullanılarak her bir bağımlı değişkenin varyans homojenliği test edilmiştir. Analiz sonucunda üç farklı tutumun varyanslarının homojen olduğu $(p>0,05)$ görülmüştür $(p>0,05)$. Akbulut (2010) çoklu varyans analizinde testin gerektirdiği varsayımlar karşılanmadığında (örneğin varyans homojenliği ihlal edildiğinde, örneklem sayısı küçük olduğunda ve eșit olmayan gruplar olduğunda) Wilk's Lambda değerinin yerine daha dirençli olduğu için Pillai Trace değerinin yorumlanmasını önermektedir. Sayıltılardan biri karşılanmadığı için Pillai Trace sonucu yorumlanmıştır. Pillai Trace testi sonuçları değişkenlerin en az birinin anlamlı bir farklılık gösterdiğini ortaya koymuştur (Pillai Trace $\left.(\lambda)=0,308, F_{(9-1125)}=14,27, p<0,05\right)$. Bağıml değişkenlerdeki çok yönlü (multivariate) varyansın $\% 10$ 'u bağımsız değişken tarafından açıklanmaktadır ( $\eta 2=0,103)$. Yukarıda Tablo 9'da tek faktörlü ANOVA sonuçları özetlenmiştir. Öznel din algısına göre dinî sembollere yönelik pozitif duygu-düşünce-davranış boyutu $\left(\mathrm{F}_{(3-375)}=43,69, p<0,05\right)$, toplumsal ayriştırma unsuru olarak dinî semboller boyutu $\left(\mathrm{F}_{(3-375)}=25,54, p<0,05\right)$ ve toplumsal saygı ve hoşgörü unsuru olarak dinî semboller boyutu ortalama puanlarının farklılaştığı görülmüştür. Scheffe sonuçlarına göre "Din benim için hiç önemli değil" diyenlerin dinî sembollere yönelik pozitif duygudüşünce-davranış düzeyi en düşük seviyededir ve bu grubun ortalama puanları din benim için önemli ve çok önemli diyen gruplardan anlamlı şekilde farklılaşmaktadır. Yine "Din benim için az önemli" diyenlerin dinî sembollere yönelik pozitif duygu-düşünce-davranış puanları din benim için önemli ve çok önemli diyenlerden anlamlı şekilde düşük çıkmıştır. Çoklu karşılaştırma testine göre "Din benim için önemli" diyen grubun dinî sembollere yönelik pozitif duygu düşünce ve davranış puanları da "Din benim için çok önemli" diyenlere göre anlamlı şekilde düşük çıkmıştır. Dinî sembollere yönelik olumlu duygu düşünce ve davranış ortalama puanları en yüksek grup, "Din” benim için çok önemli diyen gruptur. Bu grubun puanları diğer üç gruptan anlamlı şekilde daha yüksektir.

Dinin önemine göre toplumsal ayrışma unsuru olarak dinî sembolleri algılama bakımından gruplar kıyaslandığında "Din benim için çok önemlidir" diyenlerin puanları diğer gruplardan anlamlı şekilde farklılaşmaktadır. Bu grup dinî sembolleri toplumsal ayrışma unsuru olarak en düşük seviyede 
gören gruptur. "Din benim için hiç önemli değil” diyenler dinî sembolleri toplumsal ayrışma unsuru olarak görmektedir. Dinin önemini hissetme düzeyi artarken, dinî sembolleri ayrıştırıcı unsur olarak görme eğilimi azalmaktadır.

Toplumsal saygı ve hoşgörü unsuru olarak dinî semboller boyutu ortalama puanlarının dinin önemini hissetme düzeyine göre farklılaşıp farklılaşmadığına bakıldığında, sadece "Din hiç önemli değildir" diyenlerle, "Din çok önemlidir" diyenler arasında anlamlı bir fark ortaya çıkmıștır. Diğer gruplar arasındaki fark istatistiksel olarak anlamlılı seviyesine ulaşmamıştır. "Din hiç önemli değildir" diyenlerin dinî sembollere yönelik saygı ve hoşgörü puanı en düşük, "Din benim için çok önemlidir" diyenlerin ise, dinî sembollere karşı en çok saygı ve hoşgörü puanı ise en yüksektir.

Tablo 10. Cinsiyete Göre Göre Dinî Sembollere Yönelik Tutumların Karşılaştırması MANOVA Sonuçları

\begin{tabular}{llllllll}
\hline Değişken & Dinin önemi & $\mathbf{N}$ & $\overline{\mathbf{X}}$ & ss & $\mathbf{F}$ & $\boldsymbol{p}$ & Fark \\
\hline Olumlu & 1.Kadın & 247 & 84,81 & 21,10 & & & \\
Duy-Düş- & 2. Erkek & 132 & 81,71 & 20,84 & 1,86 & 0,173 & - \\
Dav & Toplam & 379 & 83,73 & 21,04 & & & \\
\hline \multirow{2}{*}{ Ayrıştırıcı } & 1.Kadın & 247 & 23,17 & 7,943 & & \\
Unsur & 2. Erkek & 132 & 23,28 & 7,08 & 0,015 & 0,902 \\
& Toplam & 379 & 23,21 & 7,64 & & & \\
\hline \multirow{2}{*}{ Saygı ve } & 1.Kadın & 247 & 20,57 & 3,30 & & \\
Hoşgörü & 2. Erkek & 132 & 20,35 & 3,50 & 0,361 & 0,548 & - \\
& Toplam & 379 & 20,49 & 3,37 & & \\
\hline
\end{tabular}

Bireylerin cinsiyetine göre dinî sembollere yönelik psiko-sosyal tutumlarının farklılaşıp farklılaşmadığını belirlemek için tek faktörlü MANOVA yapılmıştır. Box'ın M istatistiğine göre yayılma matrisinin homojenlik sayıltısının karşılanmıştır $(\mathrm{F}(6-45$ 473515,987 $)=0,995, p>0,05)$. Levene testi sonucunda ise her bir bağımlı değişkenin varyansının homojen olduğu görülmüştür $(p>0,05)$. Gruplar arası kovaryansın homojenlik sayıltısı karşılandığı için bu analizde Wilk's Lambda değeri yorumlanmıştır. Cinsiyete göre bağımlı değişkenlerin hiç birinin anlamlı bir farklılık göstermediği görülmüştür (Wilks' Lambda $\left.(\lambda)=0,006, \mathrm{~F}_{(3-375)}=0,795 p>0,05\right)$. Cinsiyete göre dinî sembollere yönelik psiko-sosyal tutumlarda bir farklılaşma tespit edilememiștir. 
Dinî Sembollere Yönelik Psiko-Sosyal Tutumlar Ölçeğinin Geliştirilmesi ve Bazı Değiş̧kenlere Göre Karşılaştırılması

Tablo 11. Eğitim Düzeyine Göre Göre Dinî Sembollere Yönelik Tutumların Karşılaştırması MANOVA Sonuçları

\begin{tabular}{|c|c|c|c|c|c|c|c|}
\hline Değişken & Eğitim Düzeyi & $\mathbf{N}$ & $\overline{\mathbf{X}}$ & ss & $\mathbf{F}$ & $p$ & Fark \\
\hline \multirow{4}{*}{$\begin{array}{l}\text { Olumlu } \\
\text { Duy-Düş- } \\
\text { Dav }\end{array}$} & 1.Lise & 33 & 76,36 & 23,92 & \multirow{4}{*}{4,09} & \multirow{4}{*}{0,017} & \multirow{4}{*}{-} \\
\hline & 2. Üniversite & 265 & 85,63 & 19,95 & & & \\
\hline & 3. Lisans Üstü & 81 & 80,54 & 22,45 & & & \\
\hline & Toplam & 379 & 83,73 & 21,042 & & & \\
\hline \multirow{4}{*}{$\begin{array}{l}\text { Ayriştırıcl } \\
\text { Unsur }\end{array}$} & 1.Lise & 33 & 25,00 & 8,22 & \multirow{4}{*}{2,05} & \multirow{4}{*}{0,130} & \multirow{4}{*}{-} \\
\hline & 2. Üniversite & 265 & 22,71 & 7,10 & & & \\
\hline & 3. Lisans Üstü & 81 & 24,12 & 8,92 & & & \\
\hline & Toplam & 379 & 23,21 & 7,64 & & & \\
\hline \multirow{4}{*}{$\begin{array}{ll}\text { Saygı ve } & \\
\text { Hoşgörü } & \end{array}$} & 1.Lise & 33 & 19,24 & 3,79 & \multirow{4}{*}{3,05} & \multirow{4}{*}{0,048} & \multirow{4}{*}{-} \\
\hline & 2. Üniversite & 265 & 20,72 & 3,27 & & & \\
\hline & 3. Lisans Üstü & 81 & 20,28 & 3,44 & & & \\
\hline & Toplam & 379 & 20,49 & 3,37 & & & \\
\hline
\end{tabular}

MANOVA sonuçları yorumlanmadan önce MANOVA analizi sayıltılarının karşılanıp karşılanmadı̆̆ı kontrol edilmiştir. Box's M istatistiğine göre yayılma matrisinin homojenlik sayıltısını karşılandığ görülmüştür $\left(\mathrm{F}_{(12-38981,881)}=1,580, p>0,05\right)$. Daha sonra Levene Testi kullanılarak her bir varyansın homojenliği test edilmiştir. Buna göre üç grupta da varyanslarının homojen olduğu görülmüştür $(p>0,05)$. MANOVA analizi incelendiğinde multivariate test sonuçlarına göre dinî sembolleri tanıma değişkeni açısından bağımlı değişkenlerden hiç birinin anlamlı farklılık göstermediği görülmüştür. (Wilks' $\lambda=0,949, \mathrm{~F}_{(6-748)}=1,705^{\mathrm{b}}$, $p>0,05)$. Araştırma grubunda yer alan üç eğitim düzeyi bakımından dinî sembollere yönelik tutumlar farklılık göstermemiştir.

Tablo 11'de verilen tek faktörlü ANOVA sonuçları dinî sembollere yönelik pozitif duygu-düşünce-davranış boyutu $\left(\mathrm{F}_{(2-376)}=4,098, p<0,05\right)$ ile dinî sembollere yönelik saygı ve hoşgörü boyutu ortalama puanları $\mathrm{F}_{(2-376)}=$ $3,059, p<0,05)$ eğitim düzeyine göre farklı gösterdiği görülse de MANOVA sonuçları esas alındığı için bu farklılıklar yorumlanmamıştır.

Dinî sembollere yönelik psiko-sosyal tutumlar yaş gruplarına göre karşılaştırılmıştır. MANOVA sonuçları yorumlanmadan Box's M testiyle grupların varyans-kovaryans homojenliği, Levene ile her bir bağımlı değişkenin varyans homojenliğine bakılmıştır. Box's $M$ istatistiğine göre yayılma matrisinin homojenlik sayıltısını karşılamadığı görülmüştür $\left(\mathrm{F}_{(12-}\right.$ 
Çiğdem GÜLMEZ \& Fatma Zehra PATTABANOĞLU

Tablo 12. Yaşa Göre Dinî Sembollere Yönelik Tutumların Karşılaştırması MANOVA Sonuçları

\begin{tabular}{|c|c|c|c|c|c|c|c|}
\hline Değişken & Dinin önemi & $\mathbf{N}$ & $\overline{\mathbf{X}}$ & ss & $\mathbf{F}$ & $p$ & Fark \\
\hline \multirow{4}{*}{$\begin{array}{l}\text { Olumlu } \\
\text { Duy-Düş- } \\
\text { Dav }\end{array}$} & 1. 18-29 yaş & 201 & 86,81 & 19,29 & \multirow{4}{*}{6,74} & \multirow{4}{*}{0,001} & \multirow{4}{*}{$1-3$} \\
\hline & 2. 30-45 yaș & 106 & 82,46 & 21,30 & & & \\
\hline & 3. 46-65 yaş & 71 & 76,50 & 23,47 & & & \\
\hline & Toplam & 378 & 83,65 & 21,01 & & & \\
\hline \multirow{4}{*}{$\begin{array}{l}\text { Ayriştırıcı } \\
\text { Unsur }\end{array}$} & $1.18-25$ yaş & 201 & 22,11 & 7,05 & \multirow{4}{*}{8,05} & \multirow{4}{*}{0,001} & \multirow{4}{*}{$1-3$} \\
\hline & 2. 26-45 yaş & 106 & 23,27 & 8,24 & & & \\
\hline & 3. 46-65 yaş & 71 & 26,28 & 7,63 & & & \\
\hline & Toplam & 378 & 23,22 & 7,65 & & & \\
\hline \multirow{4}{*}{$\begin{array}{l}\text { Saygı ve } \\
\text { Hoşgörü }\end{array}$} & $1.18-25$ yaş & 201 & 21,05 & 2,92 & & \multirow{4}{*}{0,001} & \multirow{4}{*}{$1-3$} \\
\hline & 2. 26-45 yaş & 106 & 20,26 & 3,40 & \multirow{3}{*}{8,67} & & \\
\hline & 3. 46-65 yaş & 71 & 19,19 & 4,07 & & & \\
\hline & Toplam & 378 & 20,48 & 3,37 & & & \\
\hline
\end{tabular}

kenin varyanslarının homojen $(p>0,05) \quad 3$. bağımlı değişkenin ise varyanslarının homojen olmadığı görülmüştür $(p<0,05)$. Sayıltılar ihlaledildiği için daha Pillai's Trace sonuçları yorumlanmıştır. Pillai's Trace sonucuna göre yaş grupları açısından bağımlı değişkenlerin en az biri anlamlı farklılık göstermiştir (Pillai's Trace $=0,084 \mathrm{~F}_{(6-750)}=5,483, p<0,05$ ). Bağımlı değişkenlerdeki çok yönlü (multivariate) varyansın \%3'ü bağımsız değişken yaş tarafından açıklanmaktadır $(\eta 2=0,036)$.

Tablo 12'de tek faktörlü ANOVA sonuçları verilmiştir. Yaş gruplarına göre göre dinî sembollere yönelik pozitif duygu-düşünce-davranış boyutu puanları $\left(\mathrm{F}_{(2-376)}=6,746, p<0,05\right)$ dinî sembollerin ayrıştırıcı unsur olarak anlaşılması puanları $\left(\mathrm{F}_{(2-375)}=6,746, p<0,05\right)$ ve dinî sembollere yönelik saygı ve hoşgörü boyutu ortalama puanları $\left(\mathrm{F}_{(2-375)}=8,672, p<0,05\right)$ anlamlı farklılık göstermiştir. 1 ve 2 . bağımlı değişkenin hangi yaş gruplarında farklılaştığını tespit için Post Hoc testlerden Scheffe, 3 bağımlı değişkenin hangi gruplarda farklılaştığını görmek için ise Dunnett T3 yapılmıştır. Sonuçlara göre dinî sembollere yönelik pozitif duygu-düşünce ve davranışla, dinî sembolleri ayrıștırıcı unsur olarak görme ve dinî sembollere yönelik saygı ve hoşgörü boyutlarının üçünde de 18-29 yaş grubu ile 46 ve üzeri yaş grubu arasında 18-29 yaş grubu lehine anlamlı farklılık görülmüştür. Dinî sembollere yönelik pozitif duygu düşünce ve davranış ortalama puanı ve dinî sembollere yönelik saygı ve hoşgörü puanı en yüksek grup, 18-29 yaş arası genç yetişkinlerdir. Dinî sembolleri ayrıştırıcı unsur olarak görenler ise en 
çok 46 yaş ve üzeri gruptadır.

Tablo 13. Gelir Düzeyine Göre Dinî Sembollere Yönelik Tutumların Karşılaștırması MANOVA Sonuçları

\begin{tabular}{|c|c|c|c|c|c|c|c|}
\hline Değişken & Gelir Düzeyi & $\mathbf{N}$ & $\overline{\mathbf{X}}$ & ss & $\mathbf{F}$ & $p$ & Fark \\
\hline \multirow{5}{*}{$\begin{array}{l}\text { Olumlu } \\
\text { Duy-Düş- } \\
\text { Dav }\end{array}$} & 1. $0-2400$ & 175 & 86,32 & 19,52 & \multirow{5}{*}{4,35} & \multirow{5}{*}{0,001} & \multirow{5}{*}{$\begin{array}{l}1-4 \\
2-4\end{array}$} \\
\hline & 2. 2401-4999 & 85 & 85,28 & 19,77 & & & \\
\hline & 3. 5000-7999 & 73 & 80,84 & 23,94 & & & \\
\hline & 4. 8000 ve üstü & 45 & 74,75 & 21,49 & & & \\
\hline & Toplam & 378 & 83,65 & 21,01 & & & \\
\hline \multirow{5}{*}{$\begin{array}{l}\text { Ayrıştırıcı } \\
\text { Unsur }\end{array}$} & 1. $0-2400$ & 175 & 22,43 & 7,02 & \multirow{5}{*}{4,03} & \multirow{5}{*}{0,001} & \multirow{5}{*}{$\begin{array}{l}1-4 \\
2-4\end{array}$} \\
\hline & 2. 2401-4999 & 85 & 22,94 & 7,59 & & & \\
\hline & 3. 5000-7999 & 73 & 23,24 & 8,57 & & & \\
\hline & 4. 8000 ve üstü & 45 & 26,80 & 7,77 & & & \\
\hline & Toplam & 378 & 23,22 & 7,65 & & & \\
\hline \multirow{5}{*}{$\begin{array}{l}\text { Saygı ve } \\
\text { Hoşgörü }\end{array}$} & 1. $0-2400$ & 175 & 21,04 & 2,94 & \multirow{5}{*}{4,51} & \multirow{5}{*}{0,001} & \multirow{5}{*}{$1-4$} \\
\hline & 2. 2401-4999 & 85 & 20,55 & 3,31 & & & \\
\hline & 3. 5000-7999 & 73 & 19,75 & 3,81 & & & \\
\hline & 4. 8000 ve üstü & 45 & 19,37 & 3,83 & & & \\
\hline & Toplam & 378 & 20,48 & 3,37 & & & \\
\hline
\end{tabular}

Gelir düzeyine göre dinî sembollere yönelik tutumların değişimini belirlemek için tek faktörlü MANOVA analizi yapılmıştır. Box's M istatistiğine göre yayılma matrisinin homojenlik sayıltısını karşılamadığı görülmüştür $\left(F_{(18-142737,635)}=3,320 p>0,05\right)$. Levene testi sonucunda da 1. ve 2 . bağımlı değişkende varsayansın homojen, 3. bağımlı değişkende homojen olmadığı $(p<0,05)$ görülmüștür. Saylttılar ihlal edildiği için yine Pillai's Trace testi yorumlanmıştır. Multivariate test sonuçlarına göre gelir düzeyi değişkeni açısından bağımlı değişkenlerin en az biri anlamlı farklılık göstermiştir. (Pillai's Trace $=0,059 \mathrm{~F}_{(9-1122,000)}=2,511, p<0,05$ ). Bağımlı değişkenlerdeki çok yönlü (multivariate) varyansın \%10'u bağımsız değişken yaş tarafından açıklanmaktadır ( $\eta 2=0,018)$.

Tablo 13'de tek faktörlü ANOVA sonuçları verilmiştir. Gelir gruplarına göre göre dinî sembollere yönelik pozitif duygu-düşünce-davranış boyutu puanları $\left(\mathrm{F}_{(3-374)}=4,350, p<0,05\right)$ dinî sembollerin ayrıştırıcı unsur olarak görülmesi puanları $\left(\mathrm{F}_{(3-374)}=4,031 p<0,05\right)$ ve dinî sembollere yönelik saygı ve hoşgörü boyutu ortalama puanları $\left.\mathrm{F}_{(3-374)}=4,514, p<0,05\right)$ anlamlı farklılık göstermektedir. 1. ve 2 . bağımlı değişkenin hangi gelir gruplarında farklılaştığını tespit için Post Hoc testlerden Scheffe, üç bağımlı değişkenin 
hangi gruplarda farklılaştığını görmek için ise Dunnett T3 yapılmıştır. Sonuçlara göre dinî sembollere yönelik pozitif duygu-düşünce ve davranışlar, dinî sembolleri ayrıştırıcı unsur olarak görme ve dinî sembollere yönelik saygı ve hoşgörü boyutlarının üçünde en düşük gelir grubu olan 02400 ile en yüksek gelir grubu olan 8000 ve üzeri grup arasında anlamlı farklılık görülmüştür. 0-2400 arasında gelire sahip olanların dinî sembollere yönelik olumlu duygu düşünce ve davranış puanları ile dinî sembollere yönelik saygı ortalama puanları en yüksek iken, 8000 ve üzeri gelire sahip olanların ise en düşüktür. Ayrıca 8000 ve üzeri gelire sahip olanların dinî sembolleri toplumsal yaşamda ayrıştırıcı unsur olarak görme eğilimleri gelir düzeyi 0-2400 ve 2401-4999 arasında olan gruptan anlamlı biçimde yüksektir. 5000-7999 arası grupla 8000 ve üzeri gelire sahip olanlar arasında anlamlı bir farklılık üç bağımlı değişken açısından görülmemiştir.

\section{Tartışma ve Sonuç}

$\mathrm{Bu}$ araştırma dinî sembollere yönelik psiko-sosyal tutumları belirlemede kullanılabilecek bir ölçek geliştirmek amacıyla düzenlenmiştir. Geliştirilen ölçeğin geçerlik güvenirlik analizleri yapılmış ve bazı değişkenlere göre dinî sembollere yönelik psiko-sosyal tutumlar karşılaştırılmıştır.

Ölçek geliştirme işleminde öncelikle ilgili literatür taranarak 55 sorudan oluşan madde havuzu oluşturulmuştur. Geliştirilen maddeler uzman görüşüne sunulduktan ve gerekli düzenlemeler yapıldıktan sonra 50 maddenin yer aldığı taslak ölçek Kastamonu Üniversitesi'nde farklı bölümlerde öğrenim gören 410 öğrenciye uygulanmıştır. Bu araştırmanın birinci örneklemdir. Birinci çalışma olarak isimlendirilmiştir.

Madde havuzu oluşturulurken maddelerin psikolojik olarak üç, sosyolojik olarak iki toplam beş farklı kavramsal yapı altında toplanacağı ön görülmüştür. Ancak birinci çalışmadan elden edilen verilere uygulanan açımlayıcı faktör analizi sonrasında sosyolojik iki kavramsal yapı ayrı, psikolojik üç kavramsal yapı ise birleşik görüntü vermiştir. Açımlayıcı faktör analizi neticesinde toplam 38 maddenin üç faktörde dağıldığı görülmüştür. $\mathrm{Bu}$ alt faktörler; "dinî sembollere yönelik pozitif duygu-düşüncedavranışlar", "toplumsal ayrışma unsuru olarak dinî semboller" ve "toplumsal saygı ve hoşgörü unsuru olarak dinî semboller" olarak isimlendirilmiştir. Ölçeğin madde faktör yükleri 0,45 ila 0,84 arasında değişmektedir ve maddeler toplam varyansın \%52,66'sını açılamaktadır. Elde edilen varyansın büyüklüğü ilgili kavram ya da yapının o denli iyi ölçüldüğünün göstergesi olarak yorumlanmaktadır (Büyüköztürk, 2011, s. 
171). Sosyal bilimlerde yapılan analizlerde $\% 40$ ila $\% 60$ arasında değișen açıklanan varyans oranları yeterli kabul edilmektedir (Tavşancıl, 2014). Bu sonuçlara göre ölçeğin açıklamış olduğu varyans oranı kabul edilebilir düzeydedir.

Birinci çalışmada faktör yapısı belirlenen ölçeğin güvenirliğini değerlendirmek için Cronbach Alfa iç tutarlılık katsayısından faydalanılmıștır. Cronbach Alfa değeri; 1 . faktörün 0,96, 2. faktörün 0,81 ve 3. faktörün $0,75^{\prime}$ dir. Cronbach Alfa değerinin 0,70 'in üzerinde olması ölçeğin iç tutarlılığının yüksek olduğuna işaret etmektedir (Kline, 2011, s. 70) . Buna göre her üç alt ölçek için elde edilen Cronbach Alfa değeri ölçeğin öğrenci örnekleminde tutarlı, güvenilir ölçüm yaptığını göstermektedir. Birinci çalışmada madde analizi kapsamında; alt \%27 (ölçülen tutumlara yüksek düzeyde sahip olan kişiler) ve üst \% 27'lik (ölçülen tutumlara düşük düzeyde sahip olan kişiler) gruplarının ortalama puanlarının bağımsız t-testiyle karşılaştırılmıştır. Buna göre ölçeğin ölçülmek istenen tutumlara sahip kişilerle sahip olmayan kişileri ayırt edebilme gücü yüksektir. Analiz sonuçları incelendiğinde düzeltilmiş madde-toplam test korelasyonlarının 0,52 ile 0,84 arasında değiştiği görülmektedir. Genel olarak madde toplam korelasyon değeri 0,30'un üzerinde olan maddelerin iyi ayırt edicilik özelliğine sahip olduğu kabul edilmektedir (Büyüköztürk, 2011, s. 171). Bu sonuçlar da ölçülmek istenen tutumlar açısından maddelerin bireyleri iyi derecede ayırt etme gücüne sahip olduğuna kanıt gösterilebilir.

Birinci çalışmada ölçeğin faktör yapısı belirlendikten ve güvenir ölçüm yaptığına ilişkin istatistik kanıtlar elde edildikten sonra bu faktöryel yapının farklı bir hedef kitlede korunup korunmadığını belirlemek için ikinci bir çalışma yapılmıştır. İkinci çalışmadan elde edilen verilere doğrulayıcı faktör analizi uygulanmıştır. Analiz neticesinde elde edilen uyum indeksleri üç faktörlü yapının yaşları 18-65 arasında değişen genel halk örnekleminde doğrulandığına kanıt oluşturmuştur. Yine bu çalışmada ölçümün güvenirliğine Cronbach Alfa ile bakılmış üç boyut için Cronbach Alfa değeri sırayla 0,97, 0,89, 0,84 hesaplanmıştır. Ayrıca bu çalışmada her bir faktör için ayrı ayrı yakınsak geçerlik AVE değeri ve kompozit geçerlik CR değeri hesaplanmıştır. AVE değerleri faktörler için sırayla $0,62,0,54$ ve 0,58 , CR değeri ise sirayla $0,97,0,89$ ve 0,87 'dir. $\mathrm{Bu}$ sonuçlar ölçeğin ikinci örneklemde yaptığı ölçümün iç tutarlılığının, yakınsak geçerliğinin ve kompozit güvenirliğinin yüksek olduğunu göstermiştir.

Tüm bu sonuçlar değerlendirildiğinde geliştirilen ölçeğin yapı geçerliğine ve güvenirliğe sahip olduğuna kanaat edilmiş ve böylece bazı 
çıkarımsal istatistiki analizler uygulanmıştır.

İkinci çalışmada katılımcılara büyük dinlerin Kâbe, hilal, haç, Davut yıldızı, aum gibi en bilinen sembollerinin yer aldığı küçük bir anket formu sunulmuştur. Verilen cevaplar gruplandırıldığında 0-3 aralığında doğru cevaba sahip olanların oranın \%17,4, 4-6 arası doğru cevabı olanların oranın $\% 41,4,7-9$ arası doğru cevabı olanların oranının ise $\% 41,2$ olduğu görülmüştür. Sonuçlar ulaşılan örneklemin dinî sembolleri tanıma düzeyinin yüksek olduğunu göstermiştir. Bu sonuçlar örneklemin eğitim düzeyinin yüksek olmasına bağlanabilir. Zira örneklemde eğitim düzeyi düşük olan kişiler temsil edilememiştir. Bu durum online yöntemle veri toplamanın bir dezavantajıdır. Her ne kadar eğitim düzeyi alt seviyelerde olan kişilere ulaşılmaya çalışılsa da geri dönüş alınamamıştır. Literatürde dinî sembollerin insanlar tarafından bilinme oranlarına dair çalışmaya ulaşılamamıştır. Ancak Çetin (2018) tarafından yapılan bir çalışmada bazı Alevi derneklerinin kendilerini tanımlayıcı logolar olarak kullandıkları Alevi inancına özgü sembollerin tanıma durumu sorgulanmıștır. Türk Dili ve Edebiyatı, Çağdaş Türk Lehçeleri ve Edebiyatları ile Türk Halkbilimi bölümlerinden mezun Türk Dili ve Edebiyatı öğretmen adaylarına Alevi inancıyla ilişkili üzerinde semah dönenlerin, kucağında aslan ve ceylanla Hacı Bektaş Veli'nin ve Zülfikar gibi resimlerin yer aldığı bir anket uygulanmıştır. Öğrencilerden bu sembollerin anlamları veya çağrışımları istenmiştir. Çetin, katılımcıların dernek logolarını ve Alevi inancıyla ilişkili sembolleri büyük oranda tanımadıklarını, anlamlarına dair bilgi sahibi olmadıklarını ifade etmektedir. Çetin'in de anketini yüksek eğitime sahip kişilere uygulamasına rağmen bu sonucu alması daha spesifik sembolleri sormuş olmasından kaynaklanabilir.

Dinî sembolleri tanıma düzeylerine göre; dinî sembollere yönelik pozitif duygu, düşünce ve davranış boyutu ve toplumsal ayrışma unsuru olarak dinî semboller boyutu puanları farklılık göstermemiștir. Ancak dinî sembollere yönelik saygı ve hoşgörü boyutu ortalama puanları farklılık göstermiştir. Buna göre H1 hipotezi kısmen desteklenmiştir. Sembolleri tanıma düzeyi artarken dinî sembollere yönelik saygı ve hoşgörü de artış göstermiştir. Ortaya çıkan bu durumun şaşırtıcı olmadığı söylenebilir. Zira insanların bilmedikleri şeyleri tehlikeli olarak görmeleri, bilinmedik şeyler ve durumlar karşısında endişeye kapılmaları psikolojik bir gerçekliktir. Norveç'te dinî simgelere yönelik insanların tepkilerini mülakat yöntemiyle belirlemeye çalışan bir araştırmada insanların simgelerin yanında olma veya |276| olmama durumuna göre tepkilerinin değiştiği gözlenmiştir. Kiliselerin olduğu iki sokakta 31 ve caminin olduğu bir sokakta 17 kişi ile görüşmenin 
yapıldığı araştırmada kiliselerin olduğu sokaklarda görüşülen kişilerin neredeyse tamamı (biri olumlu bakmamıştır) Hıristiyan sembollerine karşı olumlu tutum sergilemiş, Hıristiyanlık haricinde diğer dinlerin sembollerine karşı aynı tutumu sergileyip sergilemeyecekleri sorulduğunda ise 12'si olumlu 19'u ise olumsuz cevap vermiştir. Araştırmacılar kilise sokağında görüşülen kişilerin, Hıristiyanlık dışındaki dinlere karşı şüphe içinde olduklarını belirtmiş̧lerdir. Caminin var olduğu sokakta görüşülen 17 kişinin sadece 1'i oldukça mütevazi, cami işaretini gösteren tabelaya izin verilmemesi gerektiğini belirtirken, 16 kişi ise cami işaretine karşı olumlu tutuma sahip olduklarını ifade etmişlerdir. Ancak farklı dinlerin sembollerinin daha belirgin biçimde görünür olmasına katılımcıların karşı çıkacakları açılamalarından anlaşılmaktadır. Örneğin; "Bu küçük bir işaret, ama daha büyügü olsaydı protesto ederdim.", bir başkası "Minare istemiyorum, ancak bir işlevi olduğu için bu küçük cami işaretlerine karşı değilim." gibi ifadelerle göze batmadığı sürece tolerans göstereceklerini belirtmişlerdir (Løvland \& Repstad, 2015) .

Araştırmada cevabı aranan bir başka soru, dinin önemine göre dinî sembollere yönelik psiko-sosyal tutumların farklılaşıp farklılaşmadığıydı. Dinin önemi değişkenine göre, dinî sembollere yönelik psiko-sosyal tutumlar farklılık göstermektedir. Dinî sembollere yönelik pozitif duygu-düşüncedavranış boyutundan ve toplumsal saygı ve hoşgörü unsuru olarak dinî semboller boyutundan en düşük puanı alanlar, "Din benim için hiç önemli değil" diyenlerdir. Toplumsal ayrışma unsuru olarak dinî semboller boyutundan da en yüksek puanı alanlar, "Din benim için hiç önemli değil" diyenlerdir. "Din benim için çok önemlidir" diyenlerin ise, dinî sembollere yönelik pozitif duygu-düşünce-davranış boyutu ve dinî sembollere yönelik saygı ve hoşgörü boyutu puanları en yüksek, toplumsal ayrışma unsuru olarak dinî semboller boyutu puanları en düşüktür. Elde edilen bu sonuçlar H2 hipotezini desteklemektedir. Bilindiği gibi bir dine inanan ve o din içinde zuhur etmiş sembolleri yaşamının bir parçası kılanlar için, dinî semboller kutsalla ilişkilerini güçlendiren, manevi dünyalarını zenginleştiren, ait oldukları inanç topluluğunu birbirlerine bağlayan, ortak değerler etrafında birleştiren, sosyal bütünlük hissi veren, topluluk üyelerinin kendilerini güvende hissetmelerini sağlayan vasıtalar olarak değerlendirilirler. Toplumda azınlık konumunda farklı dinden olanlar veya bir dine inanmayan kişiler için ise rahatsızlık veren, kendilerini yabancı hissetmelerine neden olan, görmek istemedikleri hurafe türü şeyler olabilir. Dinî inanç türüne veya dindarlık düzeyine göre farklılıkların çıkması beklenen bir durumdur. Dinî sembollerin insanlar üzerindeki etkisinin sahip olunan inanç türüne ve 
dindarlık düzeyine göre farklılık gösterdiği sınırlı sayıda olan çalışmalarda da desteklenmiştir. Dinî sembollerin insanlar üzerindeki etkisini araştıran oldukça dikkat çekici bir araştırmada 9 Ateist, 7 Hıristiyan, 1 Hindu, 3 Yahudi olmak üzere toplam 20 sağlıklı kişiye dinî ve dinî olmayan sembollere bakarken manyetik rezonans görüntüleme yapılmıştır. Araştırmacılar dinî sembollerin beynin hem birincil görsel alanları hem de duygusal alanları üzerinde önemli etkilerde bulunduğunu, sinirsel aktivitede farklılıklar oluşturduğunu gözlemlemişlerdir. Sahip olunan dinî inançlara göre beyin tarafından dinî semboller farklı farklı algılanmış, negatif içerikli dinî semboller çoklu beyin bölgelerinde (medial oksipital alan, alt parietal, temopral ve anterior singulat kortekste) önemli deaktivasyonlara neden olmuş, pozitif dinî semboller ise, daha fazla görsel korteks aktivasyonu ortaya çlkarmıştır (Johnson vd., 2014).

Polonya'da dinî sembollerin konu edildiği bir araştırmada kamusal ortamda bulunan haçın insanlar üzerindeki etkisi gözlenmiştir. Araştırma neticesinde göre haçın varlığı ya da yokluğunun öğrencilerin pozitif ve negatif duygu durumları ve öz-güvenleri üzerinde istatistik bakımdan önemli bir etki yaratmamış ancak odada haçın olduğu ve olmadığı durumlarda katılımcların negatif duygu durumu, kilise katılımı ve dindarlık düzeyine göre farklılık göstermiştir. Haçın sergilendiği ortamda dindarlık düzeyi düşük olan kişiler daha çok negatif duygu durumu göstermiştir. Dindarlık düzeyi orta olanlarda haçın olduğu ve olmadığı durumda negatif duygu durumu benzer seyretmiş̧tir. Haçın olmadığı ortamda dindarlık düzeyi yüksek olan kişilerin ise negatif duygu durumları en yüksek düzeye ulaşmıştır. Benzer tablo kilise katılımında da görülmüştür. Haçın olduğu ortamda kiliseye nadiren gidenlerin negatif duygu durumu yüksek, haçın olmadığı ortamda ise kiliseye sık gidenlerin negatif duygu durumu en yüksek düzeyde ölçümlenmiştir (Bilewicz \& Klebaniuk, 2013).

Amerika'da yapılan bir araştırmada Noel kutlamalarına müfredatta yer veren devlet okullarında, Noel kutlamalarının Aralık ayında çocukların mutluluk ve memnuniyet düzeylerindeki etkisinin incelenmiştir. Araştırmada çocukların mutluluk düzeyinde önemli bir düşüş tespit edilmiştir. Hıristiyan olmayan çocukların \%27'si farklı, \%26'sı dışlanmış, \%24'ü sinirli, \%23'ü popüler olmadığını, \%20'si sevilmediğini hissettiğini bildirmiştir (Ribak-Rosenthal \& Russell, 1994). Sinırlı sayıda da olsa literatürde ulaşılan çalışmalar kişilerin dinî inançlarının, psikolojik ve toplumsal açıdan dinî bağllklarının, dinî sembollere yönelik tepkilerini |278| etkilediğini göstermektedir. Bu sonuçlar çalışmamızda ulaştığımız sonuçları desteklemektedir. 
Cinsiyetin dinî sembollere yönelik tutumları belirleyici bir etkisi tespit edilememiştir. Çalışmada cinsiyete göre dinî semboller yönelik psiko-sosyal tutumların farklılaşacağı ileri sürülmüştür. Literatürden ve ölçekte yer alan maddelerin de muhteviyatından dolayı kadınların dinî sembollere yönelik daha pozitif erkeklerin ise daha negatif tutumlara sahip olacağı beklenmekteydi. Ancak H3 hipotezi desteklenmemiştir. Esasında bu sonucun ortaya çıması şaşırtıcı değildir. Zira gittikçe eğitim, iş, sosyal yaşam, bilgiye erişim, becerileri geliştirme, zaman olanakları bakımından kadın erkek arasındaki farklılık azalmaktadır. Cinsiyet ve dinî sembollere yönelik tutum ilişkisini daha önce ele almış bir çalışma bulunmadığından karşılaștırma imkânı bulunmamaktadır. Ancak cinsiyetle dinî tutum ve dindarlık gibi değişkenler arası ilişkileri incelemiş çalışmalardan istifade edilebilir. Ülkemizde cinsiyet ve dindarlık farklılaşmasına değinen çalışmalarda genelde kadınların erkeklere kıyasla daha dindar oldukları hipoteziyle başlanmaktadır. Bu algıyı daha çok Batı'da yapılan araştırmaların beslediği ileri sürülebilir (Yapıcı, 2012). Türkiye'de cinsiyet dindarlık farklılaşması üzerine en geniş çalışma Yapıcı'nın meta analiz yöntemi kullanarak yaptığı çalışmadır. Örneklemi 43864'e ulaşan 78 alan araştırmanın verilerini kullanarak yaptığı çalışmada Türk toplumunda kadınların erkelerden kısmen daha dindar çıktığını ancak genel dindarlık analizinde cinsiyetler arasında farklılık olmadığını vurgulamaktadır. Ülkemizde din psikolojisi, din sosyolojisi gibi alanlarda yapılan araștırmalarda -bu araştırma da dâhilhenüz zayıf istatistiki yöntemler kullanılmaktadır. Genelde bir bağımlı ve bir bağımsız değişken arasındaki ilişkilere bakılmaktadır. Oysa sosyal hayat yalın ilişkilere indirgenemeyecek kadar kompleks değişkenlerce kuşatılmıștır. Bu nedenle cinsiyet ve dindarlık ilişkisinde aracılık edebilecek veya var olan ilişkiyi olumsuz etkileyebilecek değişkenler kovaryans analizi veya yol analizi gibi çok değişkenli istatistiklerle kontrol edildiğinde ortaya çıkan iliş̧kiler daha anlamlı okunabilecektir.

Katılımclların eğitim düzeyine göre dinî sembollere yönelik tutum puanları farklılık göstermemiştir. Buna göre $\mathrm{H} 4$ hipotezi desteklenmemiştir. Ortaya çıkan bu sonuçlar daha önce ifade edildiği gibi örneklemden kaynaklanmış olabilir. Yaşa göre dinî sembollere yönelik tutumlar farklılık göstermiştir. Her üç alt ölçekte genç yetişkinlerin (18-29 yaş) lehine puanlar 46 ve üzeri olanlardan anlamlı biçimde farklılaşmıştır. Bu sonuç H5 hipotezini desteklemiştir. Genç yetişkinlerin dinî sembollere yönelik pozitif duygu-düşünce ve davranış puanlarıyla, dinî sembollere yönelik saygı ve hoşgörü alt ölçek puanları yüksek, toplumsal ayrışma unsuru olarak dinî sembol puanları ise en düşüktür. Yaş değişkenine benzer durum gelir de 
görülmüştür. Gelir düzeyine her üç alt ölçekte ortalama puanlar farklllık göstermiștir. H6 hipotezi desteklenmiştir. Dinî sembollere yönelik pozitif duygu-düşünce-davranış boyutu ve toplumsal saygı ve hoşgörü boyutu ortalama puanları en yüksek, toplumsal ayrışma unsuru olarak dinî semboller ortalama puanı en düşük olan grup (0-2400 TL) olan kişiler iken, gelir düzeyi en yüksek olan grubun (8000 ve üzeri) pozitif duygu-düşüncedavranış ve saygı ve hoşgörü puanı en düşük, sembolleri ayrımcı unsur olarak algılama puanları ise en yüksektir. Bu sonuçlar yaş değişkenine göre dinî sembollere yönelik psiko-sosyal tutumlar arasında çıkan farklılıkla birlikte okunmalıdır. Eğitim açısından gruplar arasında ortalama puanlar farklılık göstermezken, yaş ve gelire göre farklılık ortaya çıkmıştır. Her ne kadar deneysel olamayan bir çalışmada tek yönlü çoklu varyans analizinin sonuçları nedensel bir çıkarım yapma imkânı sumansa da esas gruplar arasında ortaya çıkan bu farklılıkların nedeni hakkında bazı yorumlar yapabiliriz. Bu işi biraz kolaylaştırmak için çapraz tablo ile gruplar karşılaştırılmıştır. Çapraz tablo ile gruplar karşılaştırıldığında 18-29 yaş arasındaki genç yetişkinlerin sadece \%2'si (4 kişi) 8000 ve üzeri gelir düzeyine sahipken, aynı yaş grubunun \%78'i 0-2400 arası gelir düzeyindedir. 46 ve üzeri yaş grubundakilerin ise yine çapraz tabloya göre $\% 2,3$ 'ü 0-2400 arası gelir grubunda, $\% 41$ 'i ise 8000 ve üzeri gelir grubundadır. Bu sonuçlar birlikte değerlendirildiğinde 46 yaş ve üstü yüksek gelir seviyesine sahip kişilerin daha seküler bir yaşam biçimine sahip oluğu düşünülmektedir. Ayrıca bu kişilerin din ve dünya değerlerinin daha kalıplaşmış ve 70'li 80'li yılların Türkiyesinde seküler lisans ve lisansüstü eğitime tabi olan kişilerin daha profan bir kamusal hayatı benimseme eğilimlerinin yüksek olma olasılığına dayalı olarak 46 yaş ve üzeri kişilerin toplumsal yaşamda dinî sembollerin görünür olmasına, farklıklara saygı gösterme, kabul etme veya en azından tolerans gösterme eğilimlerinin düşük olduğu düşünülebilir. Öte taraftan 18-29 yaş arası genç yetişkinlerin 46 yaş ve üzeri kişilerle benzer bir eğitime tabi olmakla birlikte günümüzde internet vasıtasıyla daha büyük sosyal etki ve karşılaşma ağının içinde olmaları farklıklara tahammül ve saygı düzeylerini artırmış olabilir. Ancak uygun örnekleme yönteminin sınırlılıkları göz önünde bulundurulduğunda ortaya çıkan bu sonucun tesadüfi olma hususu da ihtimal dâhilindedir.

Sonuç olarak dinî sembollere yönelik psiko-sosyal tutumlar ölçeği iki çalışmada elde edilen verilerde geçerli ve güvenilir sonuçlar vermiştir. Bu araştırmada yapılan ölçümlerde geçerli ve güvenir sonuçlar ortaya çıkmış olsa da her araştırmanın dinamiği farklı olacağı için ölçeğin nicel ve nitel olarak farklılaşmış örneklemlerde kullanılması geçerlik ve güvenirlik 
konusunda daha güçlü bulgulara erişmeye imkân verecektir. Demografik değişkenler ve dinî semboller yönelik tutumlar arasındaki ilişkiye dair hipotezlerde büyük oranda desteklenmiştir. Bu sonuçlar da ölçeğin geçerliğine ek kanıtlar sunmaktadır. Öte taraftan uygun örnekleme yönteminin zayıf temsil gücüne sahip olduğu göz önüne alınarak ulaşılan sonuçları genellemek doğru olmaz ancak bu sonuçlar benzer gruplar hakkında fikir verebilir, tahminlerde bulunmaya imkân sağlayabilir.

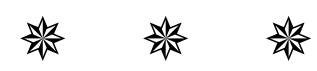

\section{KAYNAKÇA}

AKBULUT, Y. (2010). Sosyal Bilimlerde SPSS Uygulamaları. Kültür Yayıncllık.

AYDENiZ, H. (2011). Dinî Semboller, Sembolün Anlam Kaybı ve Etkilerine Gelenekselci Bir Yaklaşım (René Guénon Örneği). Ekev Akademi Dergisi, 15(48), 75-90.

BILEWICZ, M., \& KLEBANIUK, J. (2013). Psychological Consequences of Religious Symbols in Public Space: Crucifix Display at a Public University. Journal of Environmental Psychology, 35, 10-17.

BİLGìN, V. (2014). Ibadet Şekilsel, Sembolik ve Toplumsal. Emin Yayınları.

BURSAL, M. (2017). SPSS ile Temel Veri Analizleri. Anı Yayıncılık.

BÜYÜKÖZTÜRK, Ş. (2011). Sosyal Bilimler İçin Veri Analizi El Kitabı (14. bs). Pegem Akademi.

CASSIRER, E. (1980). Insan Üzerine Bir Deneme (Necla Arat, Çev.). Remzi Kitabevi.

CEVizCİ, A. (1999). Paradigma Felsefe Sözlüğü. Paradigma Yayınları.

ÇETIN, İ. (2018). İnanç Sembolleri Ve Öğrenci Algısı. İçinde O. Kurtoğlu \& A. Çamkara Erginer (Ed.), IV. Uluslararası Alevilik Ve Bektaşilik Seтроzуuти (18-20 Ekim 2018 Ankara) Bildiriler Kitabı (ss. 285-304.). Ankara Hacı Bayram Veli Üniversitesi Türk Kültürü Açısından Hacı Bektaş-ı Velî Araştırmaları Uygulama ve Araştırma Merkezi Yayınları.

ÇOKLUK, Ö., ŞEKERCIOĞLU, G., \& BÜYÜKÖZTÜRK, Ș. (2010). Sosyal Bilimler İçin Çok Değişkenli İstatistik. Pegem Akademi.

DURAND, G. (2017). Sembolik İmgelem (A. Meral, Çev.; 2. bs). İnsan Yayınları.

DURKHEIM, E. (2005). Dini Hayatın Illkel Biçimleri (Fuat Aydın, Çev.). Ataç Yayınları.

ELIADE, M. (2003). Dinlerdeki Sembollerin Araştırılması Konusunda Metodolojik Düşünceler. İçinde M. Eliade \& J. M. Kitagawa (Ed.), \& M. 
Aydın, M. Şahin, \& M. Soyhun (Çev.), Dinler Tarihinde Metodoloji Denemeleri (ss. 103-126). Din Bilimleri Yayınları.

ELIADE, M. (1992). Imgeler ve Simgeler (Mehmet Ali Kılıçbay, Çev.). Gece Yayınları.

FORNELL, C., \& LARCKER, D. F. (1981). Evaluating Structural Equation Models with Unobservable Variables and Measurement Error. Journal of Marketing Research, 18(1), 39-50.

FROMM, E. (1992). Rüyalar Masallar Mitoslar (A. Arıtan \& K. H. Ökten, Çev.).

GÜÇLÜ, A. B., UZUN, E., \& YOLSAV, H. (2002). Sarp Erk Ulaş, Felsefe Sözlüğü. Bilim ve Sanat Yayınları.

HOAD, T. F. (Ed.). (2002). Symbol. İçinde The Concise Oxford Dictionary of English Etymology. Oxford University Press.

JOHNSON, K. D., RAO, H., WINTERING, N., HU, S., ZHU, S., KORCZYKOWSKI, M., JOHNSON, K., \& NEWBERG, A. B. (2014). Pilot Study of the Effect of Religious Symbols on Brain Function: Association With Measures of Religiosity. Spirituality in Clinical Practice, 1(2), 82-98.

JUNG, C. G. (2009). İnsan ve Sembolleri (A. N. Babaoğlu, Çev.; 4. bs). Okuyan Us Yayınları.

JUNG, C. G. (2016). Analitik Psikoloji Sözlüğü (Nur Nirven, Çev.). Pinhan Yayıncillk.

KIZIL, H. (2018). İşlevleri Açısından Dini Sembol. Düsbed, 21, 30-41.

KLINE, R. B. (2011). Principles and Practice of Structural Equation Modeling. Guilford Press.

KOÇ, T. (2015). Din Dili. İz Yayıncılık.

LØVLAND, A., \& REPSTAD, P. (2015). Religious Symbols in Public Spaces Asking People in and Out of Context. Nordic Journal of Religion and Society, 28(2), 155-170.

MAZUMDAR, S., \& MAZUMDAR, S. (2009). Religion, Immigration, and Home Making in Diaspora: Hindu Space in Southern California. Journal of Environmental Psychology, 29, 256-266.

RIBAK-ROSENTHAL, N., \& RUSSELL, T. T. (1994). Dealing with Religious Differences in December: A School Counselor's Role. Elementary School Guidance and Counseling, 28, 295-301.

SCHMITT, M. T., DAVIES, K., HUNG, M., \& WRIGHT, S. C. (2010). Identity Moderates the Effects of Christmas Displays on Mood, Self-esteem, and Inclusion. 46(6), 1017-1022. 
SEÇER, İ. (2017). SPSS ve LISREL ile Pratik Veri Analizi (3. bs). Anı Yayıncllık. SIGMUND, F. (2005). Yaşamım ve Psikanaliz (Kamuran Şipal, Çev.). Say Yayınlarl.

SPILKA, B. (2013). Dini Pratik, Ritüel ve Dua (R. F. Paloutzian \& C. L. Park, Ed.; Ç. Özer, Çev.; C. 2). Phonix.

STRUCK, PETER T. (2005). Symbol and Symbolism. İçinde Jones, Lindsay (Ed.), Enchclopedia of Religion (2. Baskl, C. 13). Thomson Gale.

TABACHNICK, B., \& FIDELL, L. (2010). Using Multivariate Statistics. Pearson.

TAVŞANCIL, E. (2014). Tutumların Ölçülmesi ve SPSS İle Veri Analizi. Nobel Yayınları.

TDK. (2020). Simge. İçinde Güncel Türkçe Sözlük. https://sozluk.gov.tr/

TILLICH, P. (1957). Dynamics of Faith. Harper \& Brothers.

TILLICH, P. (2000). İmanın Sembolleri (A. Çınar, Çev.). Uludağ Üniversitesi İlahiyat Fakültesi Dergisi, 9(9).

TOKAT, L. (2012). Dinde Sembolizm (2. bs). Ankara Okulu Yayınları.

ULUÇ, T. (2015). İbn Arabî'de Sembolizm. İnsan Yayınları.

YAPICI, A. (2012). Türk Toplumunda Cinsiyete Göre Dindarlık Farklılaşması: Bir Meta-Analiz Denemesi. Frrat Üniversitesi İlahiyat Fakültesi Dergisi, 17(2), 1-34.

YAVUZ, Ö. F. (2006). Kur'an'da Sembolik Dil. Ankara Okulu Yayınları.

ZEYREK, N. (2016). Gelenekçi Ekolün Bakış Açısına Göre Sembol, Simge ve İşaretin Temsil Kategorileri. Uludağ Üniversitesi Fen Edebiyat Fakültesi Sosyal Bilimler Dergisi, 20(31), 195-211. https://doi.org/10.21550/sosbilder.290960.

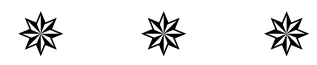




\section{THE DEVELOPMENT OF THE SCALE OF PYCHOSOCIAL ATTITUDES TOWARD RELIGIOUS SYMBOLS AND THE COMPARISON ACCORDING TO SEVERAL VARIABLES}

\section{Extended Abstract}

Religious symbols have been an integral part of human life since the first civilizations. The symbols that play an intermediary role in human communication with the sacred have emerged in the form of concepts, spaces, shapes, or rituals. However, the place, value and effect of religious symbols are not clear in human life that has become secular and cosmopolitan today. Moreover, there are very limited scientific studies devoted to the subject. One of the prerequisites for opening a concept or a phenomenon to discussion in accordance with scientific principles and methods is to have measurement tools suitable for the problem. Based on these reasons, it is aimed to develop an attitude scale towards religious symbols, to make validity and reliability analysis and to make comparisons according to some personal variables.

For this purpose, a draft scale was developed by scanning the relevant literature and taking the opinions of experts. This draft scale was applied to 410 students studying at various faculties of Kastamonu University. Exploratory factor analysis (EFA) was performed on these data. As a result of the analysis, 38 items were collected under 3 sub-factors. The first dimension is called "positive emotions-thoughts-behaviors towards religious symbols", the second dimension is "religious symbols as an element of social separation" and the third dimension is "religious symbols as an element of social respect and tolerance". The internal consistency of the scale

a Asst. Prof., Kastamonu University, gulmezcigdem@gmail.com

b Assoc. Prof., Kastomu University, f.zehrapattabanoglu@hotmail.com 
was examined with Cronbach Alpha. The Cronbach Alpha value of the 1st factor is 0.96 , of 2 nd factor 0.81 , and of the 3rd factor as 0.75 .

In the second phase, the scale was applied to 403 people. Confirmatory factor analysis of the scale was performed on the data obtained from this sample. CFA fit indices are as follows; $\left[x^{2}=1526.95, \mathrm{sd}=659, \mathrm{P}\right.$-value $\left.=0.000\right], x^{2} /$ $\mathrm{df}=2.31, \mathrm{RMSEA}=0.081, \mathrm{NFI}=0.96, \mathrm{NNFI}=0.98, \mathrm{PGFI}=0.90, \mathrm{CFI}=0.98, \mathrm{IFI}$ $=0.98, \mathrm{GFI}=0.87, \mathrm{AGFI}=0.89$. For the reliability analysis of the data obtained from the second sample, the Cronbach's Alpha value, composite reliability CR and convergent validity (AVE) values were calculated separately on the basis of dimensions. The Cronbah Alpha value is 0.97 for the 1st Factor, 0.89 for the 2 nd Factor, and 0.84 for the 3 rd Factor. AVE values for factors are $0.62,0.54$ and 0.58 , respectively. The CR value is $0.97,0.89$ and 0.87 , respectively. These results showed that the internal consistency, convergent validity and composite reliability of the measurement made by the scale in the second sample were also high.

After determining the valid and reliable measurement capacity of the scale of psychosocial attitudes towards religious symbols, inferential statistical analysis were conducted in order to compare the attitudes towards religious symbols according to some demographic variables. Comparing psychosocial attitudes towards religious symbols according to the level of recognition of religious symbols, the mean scores of respect and tolerance towards religious symbols differed. While the recognition level of symbols increased, respect and tolerance towards religious symbols also increased. When the recognition level of symbols increased, respect and tolerance towards religious symbols also increased. Psychosocial attitudes towards religious symbols also vary according to the importance of religion in the person. While the average scores of those who said "religion is very important" from the first and third factors were the highest, those who said "religion is not important at all" got the highest average scores from the second sub-factor. When the psychosocial attitudes towards religious symbols were compared according to gender and education variables, no statistically significant difference was found. However, when the psychosocial attitudes towards religious symbols were compared according to age and income variables, the average scores of young adults (18-29 years old) in all three subscales differed significantly in favor of young adults from the advanced middle age group (46 years and over).

As a result, a measurement tool with psychometric competence that can be used to measure psychosocial attitudes towards religious symbols has been 
introduced. The scale has a structure in which each factor is scored in Likert form ("I don't agree at all = 1", I disagree $=2$, I partially agree $=3$, I agree $=4$, I totally agree $=5$ "). The scale made valid and reliable measurements in two different samples. However, since the dynamics of each study will be different, using the scale in samples that are quantitatively and qualitatively differentiated will allow access to stronger findings about validity and reliability. Hypothesis on the relationship between demographic variables and attitudes towards religious symbols have been largely supported. On the other hand, it would not be correct to generalize the results obtained considering that the appropriate sampling method has poor representation power. In addition, these results can give an idea about similar groups and allow us to make predictions.

Keywords: Psychology of religion, Philosophy, Psychosocial attitude, Religious symbols, Scale, Validity, Reliability.

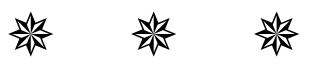

